\title{
How do Global Trade Rules Evolve? Strategic Sequencing in International Economic Law
}

\author{
Matthew Castle円
}

How do global trade rules evolve? When the EU revised the investment chapter of its recent trade deal with Canada it was understood that the amendments were motivated by domestic concern over the design of a different agreement, yet-to-be-completed, with the United States. Yet there is no formal link between these two agreements. This article argues that agreements create precedent that shapes subsequent negotiations, and policymakers act accordingly. Specifically, states sequence agreements, using negotiations with likeminded or relatively less important partners to establish model rules for subsequent use where negotiations will be more challenging. A two-stage regression analysis on PTA sequencing from 1965 to 2016 and qualitative probes from the UK and New Zealand support the argument. Legal language has a way of sticking around, and states know it. Accordingly, states sign agreements with an eye to the future.

Word count: 11,955

*I thank Krzysztof Pelc, Leo Baccini, and Ed Mansfield for many helpful comments. I also thank Vincent Arel-Bundock, Guillaume Beaumier, Mark Brawley, Alice Chessé, Arc Zhen Han, Lucy King, Lisa Lechner, Abe Newman, Lou Pingeot, participants at workshops and talks at McGill University, IPES (2017), and several interview participants. I gratefully acknowledge funding from the Fonds de recherche du Québecsociété et culture (FRQSC) in the form of a Bourse de doctorat en recherche pour étudiants étrangers (file no. 193907). Naturally all errors remain mine.

${ }^{\dagger}$ Lecturer, Political Science and International Relations, Victoria University of Wellington. matthew.castle@vuw.ac.nz 


\section{Introduction}

Trade and trade deals have become among the most politically-charged issues in international politics. At the heart of this contestation lies disagreement about how to regulate novel issueareas in the trade regime. With liberalization at the World Trade Organization (WTO) at a standstill since 2008, negotiators have inked innovative clauses in a growing number of preferential trade agreements (PTAs) on topics including intellectual property, foreign investment, trade in services, and state-owned enterprises 1 In these new areas, negotiations must reconcile different views about how to regulate 'behind-the-border' issues in areas of traditional domestic authority. Because these are 'unsettled' areas of international law in which common approaches have not yet been developed, negotiations on these new issues are more fraught ${ }^{2}$ How do negotiators innovate in these areas?

I argue that negotiators establish precedent strategically. Because negotiators know that agreements set precedent, they have an incentive to sequence agreements: to take advantage of negotiations with less-important or less-threatening partners to establish favourable precedent to use in later deals. By institutionalizing negotiating positions, negotiators improve the odds of replicating preferred terms in later deals, including with more economically or strategically important partners. Domestic politics is central to the establishment of precedent. Precedent embeds new norms in domestic regulatory regimes and creates political and rhetorical resources for domestic constituents who can mobilise around specific clauses. In so doing, precedent can provide negotiators with a credible argument that past agreements represent what is politically necessary for domestic ratification, raising the likelihood of novel

\footnotetext{
${ }^{1}$ Lechner 2016; Milewicz et al. 2016.
} 2 Castle and Pelc 2019. 
norms being accepted. Legal commitments have a way of sticking around, and negotiators know it. Thus, they sign agreements with an eye to future deals.

Developments in EU trade policy illustrate the argument. In late 2015, EU trade officials requested the renegotiation of the investor-state clause in the Comprehensive Economic and Trade Agreement (CETA) with Canada. The reason cited for the re-negotiation was concern not just over CETA, but over the Transatlantic Trade and Investment Partnership (TTIP) with the United States (US), yet to be completed. A member of Ontario's legal team during the CETA talks commented that should Canada agree to the EU requests, "the Americans will be pretty pissed off at us". Quoting the official, a news report explains that "[i]f Canada agrees to a compromise the U.S. doesn't want, 'it's like throwing a finger into their eye." "’3

The potential for CETA to set a precedent for subsequent European (and Canadian) negotiations helps to explain the EU's request to amend CETA, as well as the Canadian concern that the US might be affected by the terms of an EU-Canada deal. By revising CETA, EU negotiators created a precedent that could be used in negotiations with the US, which at that stage held opposing views on the regulation of investor-state disputes. Although TTIP talks faltered, Canadian negotiators would go on to propose the revised CETA investment court system during negotiations on the US-Mexico-Canada Agreement (USMCA). Illlustrating how the 'precedent' of past deals shifts future negotiating positions. Does this anecdote reveal a wider strategy of 'sequencing'? The argument's observable implication is that countries should innovate in agreements that are less well-predicted by

\footnotetext{
${ }^{3}$ Canadian Broadcasting Company, 21 January 2016. http://www.cbc.ca/m/touch/politics/story/ 1.3412943

${ }^{4}$ The Globe and Mail, September 14 2017, A1.
} 
the factors typically used to explain entry into a trade deal. I test the argument using a two-stage regression analysis of data on countries' trade agreement negotiations from 1965 to 2015. I predict countries' entry into a PTA using a political and economic gravity model. I use predicted probabilities of PTA entry to identify under-predicted agreements as cases of ExCEssive Bilateralism $I^{5}$ In second-stage regressions, I find that excessive PTAs are more ambitious according to the Design of Trade Agreements (DESTA) depth measure.6 I expect countries will be more likely to sequence if they have a clearer demonstrated concern for the evolution of global trade norms (as proxied by their stated concern for the systemic implications of WTO disputes). This indeed appears to be the case; those countries' excessive PTAs are more likely to be deep. To make sure that the results are not driven by peculiarities of DESTA, I replicate the tests using data on trade and the environment 7 I show that underpredicted agreements are more likely to introduce new norms in this area.

I further test the argument qualitatively against the record of agreements signed by New Zealand and announced by the UK following the vote to leave the EU. Both New Zealand and the UK have justified negotiations with less economically-important partners as precedent-setting opportunities. Governments are aware of the precedent that agreements set for future negotiations and they use it to their advantage.

\footnotetext{
5 Baier and Bergstrand 2004.

6 Dür, Baccini, and Elsig 2014 .

'Morin, Dür, and Lechner 2018
} 


\section{Sequencing and precedent in international law}

\subsection{What explains PTAs?}

PTAs are typically explained by the relationship between signatories and by countries' domestic political economies. This view balances the cost of agreement (loss of policy autonomy) against the economic or political benefits of a deal. Because commitments are balanced against benefits, we should expect new treaty language to emerge where it matters most.

Viewing agreements as a function of the economic and political relationship between countries, as in the 'gravity model' approach 8 is central to prevailing explanations for PTAs. One dominant explanation holds that trade agreements enable governments to make credible commitments not to adopt protectionist policy.9 In other political economy explanations for PTAs, trade policy reflects lobbying by actors seeking to internalize the economic externalities created by barriers to trade 10 In either case, the costs and benefits to different societal groups tell us about the political demands faced by negotiating governments; these demands are explained by the relationship between PTA partners. Demands for protection from import-competing groups and demands for market access from exporters will likely be stronger where countries trade more with one another: higher anticipated costs or benefits help groups to overcome barriers to collective action to influence policy ${ }^{11}$

As well as predicting PTA partners, this approach helps to predict agreement scope. As agreements go deeper into the domestic policy realm, they limit increasing amounts of policy autonomy. To offset this political cost, greater commitment should be balanced by

\footnotetext{
8 Mansfield and Milner 2012; Baier and Bergstrand 2004

${ }^{9}$ Mansfield, Milner, and Rosendorff 2002

${ }^{10}$ Mattli 1999; Osgood et al. 2017.

${ }^{11} \overline{\text { Olson } 1965 .}$
} 
greater economic gain $\sqrt{12}$ or greater flexibility. Hence, cost and benefit should be positively correlated: those agreements that have the greatest scope should be signed with the most important economic partners.

In short, prevailing explanations for PTAs center on the relationship between signatories. If we are searching for new norms, we should find them in the agreements where they will make the greatest impact. Yet, we also know that negotiators re-use legal text from previous agreements ${ }^{13}$ Even as they begin to explore new areas of legal innovation, negotiators also draw on past legal norms ${ }^{14}$ Whose (prior) text is used may be explained by power ${ }^{15}$ by efficiency considerations ${ }^{16}$ or through some other combination of competition effects, consensus on best practice (learning), emulation, or coercion ${ }^{17}$ Yet concern for future negotiations remains under-explained, despite anecdotes that suggest that forward-looking concern has a meaningful impact on negotiations.

CETA provides one anecdote of forward-looking innovation (above). The US-MexicoCanada Agreement (USMCA; the renegotiated NAFTA) provides another. USMCA Article 4 of Chapter 33 (Macroeconomic Policies and Exchange Rate Matters) commits parties to maintaining a market-determined exchange rate regime; avoiding competitive devaluation; and adopting economic policy that will support exchange rate stability. The chapter also includes requirements for transparency and reporting on interventions in foreign exchange markets. Yet the USMCA signatories maintain exchange rates that are already free of intervention, and the US has accused neither Canada nor Mexico of currency manipulation.

\footnotetext{
${ }^{12}$ Baldwin 2012

${ }^{13}$ Allee and Elsig 2019, Alschner and Skougarevskiy 2015

${ }^{14}$ Morin, Pauwelyn, and Hollway 2017. See also Alter and Meunier 2009.

$15 \overline{\text { Allee and Lugg 2016. }}$

${ }^{16}$ Peacock, Milewicz, and Snidal 2019.

${ }^{17}$ Morin and Gold 2014.
} 
Instead, the intent of negotiators seems almost entirely to establish treaty language that can be used with other partners 18

Considerations of future negotiations appear to affect the decisions that negotiators make about PTA design. Yet the traditional view of PTAs does a poor job of explaining negotiation linkages, while recent work on the reproduction of legal text does not theorise such forward-looking considerations. In other words, theories about diffusion or language re-use explain negotiators' use an 'off-the-shelf' model, but not the initial design of what gets placed on the shelf.

\subsection{Theory: Path-dependence invites strategic behaviour}

I argue that negotiators design trade agreements with an eye to their precedential value: the influence their terms can have on future deals. I draw on historical institutionalism to explain why legal norms might establish precedent. I then build on the negotiation literature to explain how trade policymakers might establish and leverage this precedent. Norms create path-dependencies, and savvy negotiators bet on it.

An historical institutionalist perspective helps to explain the politics behind precedent at domestic and international levels. For historical institutionalists, institutional context is central to understanding political action 19 and decisions over institutional design alter subsequent political interactions ${ }^{20}$ Institutional designs may lock in a balance of power between relevant actors, create positive feedback mechanisms that benefit new stakeholders, increase returns to beneficiaries, or generate self-reinforcing dynamics. These effects alter

\footnotetext{
${ }^{18}$ Bergsten 2017, Segal 2018.

${ }^{19}$ Mahoney and Rueschemeyer 2003; Steinmo and Thelen 1992.

${ }^{20}$ Pierson 2000.
} 
the domestic political landscape, meaning that political outcomes like legal norms are likely to become path-dependent. Thus Newman explains how relatively less powerful European states were able to have a disproportionate influence over standard-setting in data-privacy (vis-à-vis the US), because of the earlier development of powerful regulatory capacity at the national and European level ${ }^{21}$ Similarly, Newman and Posner explain the surprising convergence in financial regulations between the EU and the US by demonstrating that the prior establishment of 'transnational soft law' created policy templates that acted as 'disruptors' in domestic political contests by providing reform-minded actors with political resources 22

How might the above insights be relevant to trade negotiations? As commonly described, trade negotiations are a "two-level game" in which negotiating agencies must engage with domestic stakeholders and foreign counterparts, often simultaneously. ${ }^{23}$ During talks, negotiators must balance and communicate domestic constraints that are delineated by previous negotiating outcomes. On the one hand, the political power of social actors is shaped by prior contests: previous 'winners' benefit from past negotiation outcomes, whether protective or liberalizing. On the other hand, negotiating positions are derived from current domestic regulatory regimes, which themselves reflect the outcomes of past negotiations: the ratification and implementation of international agreements may amend domestic law where necessary for compliance. In this way, a country's past policy commitments create political and institutional constraints at the domestic level that shape the outcomes that negotiators can achieve during international negotiations. Because negotiators understand

\footnotetext{
${ }^{21}$ Newman 2008 .

${ }^{22}$ Newman and Posner 2016

${ }^{23}$ Putnam 1988.
} 
the requirement to satisfy domestic constituents and legislators, prior agreements credibly communicate an outcome that can be accepted domestically.

In line with the 'paradox of weakness', prior agreements may support negotiators' 'defensive' interests by communicating a negotiator's constraints ${ }^{24}$ Japan's defence of a non-zero tariff on beef in its agreement with Australia credibly signals to later partners that reducing beef tariffs to zero is politically impossible.25 Equally, precedent may support a country's 'offensive' interests. A negotiator will face an easier time persuading their counterpart that a particular level of market access or norm is required for domestic ratification if their arguments are supported by the precedent of prior agreements.

Otherwise put, the precedent of previous policy can have a material outcome on subsequent negotiations. As Crump and Moon put it, precedent can "serve as a rule, standard, or guide in establishing negotiated decisions" ${ }^{26}$ Yet our understanding of the creation of that precedent is more limited. I argue that because precedent affects bargaining outcomes, negotiators have incentives to behave strategically, setting rules with the aim of influencing the course of future negotiations. Some negotiation theorists have acknowledged this possibility for strategic behavior. Crump proposes that although precedent may emerge unintentionally because of path-dependencies, it may also be designed strategically[27 Thus one of the advantages of the US-Singapore agreement would be to establish a 'model' for the US ${ }^{28}$ And Meunier and Morin suggest that negotiators who are aware of the complex legal environment in which they operate may seek to craft rules with a view to setting a

\footnotetext{
${ }^{24}$ Schelling 1960 De Bièvre 2018.

${ }^{25}$ This was a sticking point in negotiations for the Japan-Australia FTA and for the TPP.

${ }^{26}$ Crump and Moon 2017.

${ }^{27}$ Crump 2016: Crump and Moon 2017.

${ }^{28}$ Crump 2016
} 
precedent for future negotiations ${ }^{29}$ Yet these suggestions are relatively under-theorised and under-tested.

I conceive of the precedent-setting game as one in which negotiators seek to bring (future) negotiation outcomes closer to their ideal-points by altering the bargaining environment between themselves and future counterparts. One way of doing so is by creating and communicating information about the nature of domestic constraints and thereby of the form of an agreeable outcome (the 'win-set') 30 Previous agreements crystallize actor demands and institutional environments around specific outcomes, which make it easier for international negotiators to push for those outcomes.

Consider the hypothetical emergence of new norms in the trade regime over which countries have conflicting preferences. Country $A$ prefers a novel issue $x$ to be regulated in trade agreements. Assume for simplicity that $x$ varies in a linear fashion along a single dimension that runs from weak to strong disciplines. A prefers $x$ to be regulated with strong disciplines. But other countries, including $B$, are reluctant and would prefer not to introduce this novel issue $x$. If $x$ is introduced, $B$ would prefer weak disciplines (see Figure 1).

Figure 1: Bargaining over issue $x$ with precedent

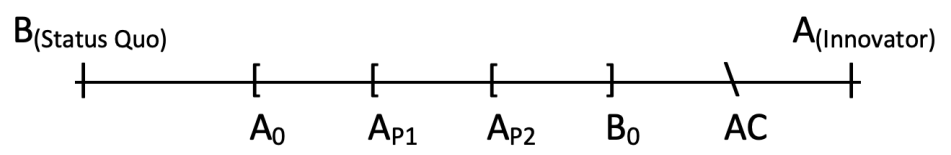

Figure presents bargaining positions over a new issue $x$. Ideal-points are at either end of the continuum. Reservation values without a precedent are denoted by ' $\mathrm{A}_{0}$ ' and ' $\mathrm{B}_{0}$ '. $A$ 's reservation values with successive precedents are denoted by ' $\mathrm{A}_{\mathrm{P} 1}$ ' and ' $\mathrm{A}_{\mathrm{P} 2}$ '. ' $\mathrm{AC}$ ' denotes the result of a PTA between $A$ and $C$.

Without a precedent, $A$ 's negotiators will find it more difficult to understand and

${ }^{29}$ Meunier and Morin 2015. 
to communicate the nature of the domestic demands they face. This makes the 'zone of possible agreement' more difficult to specify, increasing the likelihood of a failed negotiation on $x$ 31 $B$ 's bargaining position (seeking the status quo of no regulation) is likely to be stronger than $A$ 's. The status quo represents a focal point ${ }^{32}$ meaning $B$ can pull the result of bargaining towards its ideal-point. Yet if $A$ first establishes a precedent with $C$ at point 'AC', $A$ 's negotiators are able to more credibly argue during talks with $B$ that they require an ambitious outcome on issue $x$ in order to make a deal pass muster domestically: A's negotiators can limit their ability to compromise on $x$ by creating domestic actor expectations and institutional constraints that shift $A$ 's reservation value to $A_{\mathrm{P} 1}$. If $A$ then signs an additional deal at AC, $A$ may be able to argue that its reservation point lies at $\mathrm{A}_{\mathrm{P} 2}$.

$C$ ( $A$ 's first partner) may agree to innovate with $A$ for several reasons. The partners may share a forward-looking interest in developing new norms. $C$ may also accept $A$ 's proposals as part of a package deal which offers sufficient other benefits that it can accept the new norms even if $C$ has no strong interest in the issue. Finally, $C$ may be a smaller partner who is a 'rule-taker' in international negotiations.

This model fits with the anecdote about US $(A)$ negotiators' introduction of disciplines on currency manipulation $(x)$ with Mexico and Canada $(C)$ in order to increase the likelihood of a successful future negotiation with would-be manipulators $(B)$. Bergsten suggests that "the practical impact of adding currency issues to NAFTA [USMCA] would be modest or even nonexistent at present. However, this should make it relatively easy to add currency to the new NAFTA and thus set a useful precedent for other trade agreements where it might

\footnotetext{
${ }^{31}$ Odell and Tingley 2016.

${ }^{32}$ Schelling 1960 .
} 
be more relevant" 33 And indeed, the Trump administration extracted similar commitments from South Korea in a side-agreement during re-negotiations on the Korea-US Free Trade Agreement (KORUS) ${ }^{34}$

The theory extends insights from the negotiation literature. Crump has explored how past, present and future negotiations may be linked through precedent. Previous precedent may be accepted where it is recent, relevant, created legitimately (not through coercion), and where it accords with cultural practice. As part of bargaining, negotiators attempt to adopt, rebuff, refute, or avoid precedent ${ }^{35}$ Crump and co-authors have also argued that negotiators may seek to establish a precedent strategically to avoid 'bad' precedent or to establish 'good' precedent ${ }^{36}$ Yet political context plays little part in these important insights about negotiation dynamics. How does the use or creation of precedent fit with political science accounts of the importance of interests and institutions at the domestic level? Adopting an historical institutionalist lens allows us to develop a theory that integrates both domestic and international levels, in line with political science perspectives.

It is likely that not all countries will sequence. Trade negotiations are costly. Countries with high legal capacity and developed trade bureaucracies have greater resources with which to engage in precedent-setting behaviour where the immediate economic benefits may be less clear ${ }^{37}$ I expect countries to sequence if they have a demonstrable interest in the evolution of global trade norms and the legal capacity to advance those interests.

${ }^{34}$ The Whitehouse, "President Donald J. Trump is Fulfilling His Promise on the United States-Korea Free Trade Agreement and on National Security" (September 24, 2018). https://www.whitehouse.gov/briefingsstatements/president-donald-j-trump-fulfilling-promise-united-states-korea-free-trade-agreement-nationalsecurity

उ5 Crump 2016

${ }^{36}$ Crump 2007, 143; Crump 2016, Crump and Moon 2017.

${ }^{37}$ Pelc 2014.
} 
One might object that powerful states will be able to replicate preferred agreement terms and will reject the positions of less powerful states even where these are supported by precedent. But this is not simply a theory about large states exploiting small states to advance their preferences. I expect small countries may also sequence, and that economic importance may not correspond strictly with country-size. Indeed, sequencing may provide benefits to smaller states to overcome their size. Precedent may constitute an 'issue-specific power' that relates to the ability to shape outcomes in particular areas, due to particular resources (and constraints) in those areas. Previously agreed clauses may also enable states to engage in agenda-setting, guiding the negotiations on specific chapters in a trade deal. ${ }^{38}$ Moreover, even if negotiators cannot successfully replicate specific previous terms, precedent may strengthen their hands and thereby enable the package deal of negotiations to better resemble preferred outcomes.

Of course, innovation may also take place in contexts (like North America, or Europe) where agreements are well predicted by trade ties. The argument here is not that states only use under-predicted PTAs to set favourable precedents. It is rather that the benefits of sequencing provide an additional motivation for signing agreements, even where economic and political benefits are less compelling.

\subsection{Testable implications}

If the design of agreements reflects the economic and political relationship between signatories, we should expect agreements that are poorly predicted by the economic relationship between members to be less ambitious, since they are less economically beneficial. If instead ${ }^{38}$ Tallberg 2008. 
the sequencing argument is correct, it would instead suggest that poorly predicted agreements deliver an alternative benefit in the form of useful precedent. Agreements that are less likely should, counter-intuitively, have more ambitious coverage of issue-areas.

H1: Agreements that are not well predicted by the economic and political relationship between their members are more ambitious in scope than better-predicted agreements.

Though precedent is valuable, I do not expect all countries are equally likely to sequence. Some countries may be disinclined to use trade agreements to achieve 'behind the border' regulatory aims, and so may be less keen on normative innovation. Others may wish to innovate, but lack the capacity to do so. Accordingly, I expect countries will be more likely to sequence if they have a clear interest in the development of trade norms, and the political and bureaucratic resources to expend on trade policy.

H2: The positive relationship between low-prediction and high-ambition of agreements will be stronger for countries that demonstrate the greatest concern for the legal norms of the global trade regime.

\section{Method and data}

I test my hypotheses quantitatively and qualitatively. I first measure PTA under-prediction, and examine the effect of this under-prediction on the depth of cooperation and the likelihood of innovation in the agreement. I use a directed dyad-year gravity dataset. Each countrypair appears twice so that I can analyze the pair's entry into a PTA in the context of both countries' other agreements. I then turn to qualitative evidence drawn from negotiations by the UK and New Zealand. 


\subsection{Analytical approach}

To test the argument quantitatively we need a measure of 1) the importance of negotiating partners, and 2) normative innovation. For the first, I rely on the most widely-established approach for predicting trade agreements, the economic gravity model ${ }^{39}$ Agreements that are 'under-predicted' or 'excessive' are those where the relationship between signatories does not seem to warrant a deal-between signatories that are relatively unimportant trade partners for one another.

The Design of Trade Agreements (DESTA) dataset provides us with a way of capturing novelty in the trade regime with its two measures of agreement 'depth' (described in more detail below). The depth variables, while capturing the extent of cooperation, also tell us about the scope of cooperation as they measure the number of issue-areas that are regulated and the degree of cooperation within those issue-areas 40 Greater depth indicates more ambitious regulation of novel issue-areas.

One may worry that DESTA does not sufficiently capture innovation in particular issue-areas, or that the results are driven by some peculiarity of the DESTA data. Thus, I turn to one of the most topical issues to emerge in the trade regime in recent years: the environment. Using data from the TRade \& ENvironment Database (TREND) ${ }^{11}$ I build two complementary measures of innovation in environmental norms. The first is the proportion of environmental norms that are novel to a particular agreement, while the second is a count of the novel norms in an agreement. This directly captures novelty by identifying the first time that specific norms in this area appear in PTAs. For instance, the norm that it

\footnotetext{
$3^{30}$ Baier and Bergstrand 2004, Baier, Bergstrand, and Mariutto 2014 Mansfield and Milner 2012.

${ }^{40}$ Dür, Baccini, and Elsig 2014

${ }^{41}$ Morin, Dür, and Lechner 2018
} 
is "inappropriate to encourage trade by relaxing environmental measures" (TREND norm X2.01.01. ${ }^{42}$ appears for the first time in the 2000 agreement between the United States and Jordan, so I identify this norm as an innovation of that agreement.

With the above measures in hand, I estimate a logit gravity model and calculate predictive probabilities for PTA entry. I derive a binary variable, coded 1 if countries are predicted to enter into a PTA, and 0 if not. Comparing this to actual PTA entry, I identify non-predicted PTAs as instances of ExCESSIVE BILATERALISM ${ }^{43}$ I use the distribution of PTAs as a guide to the predicted probability, but I cannot create a time-invariant threshold based on the overall incidence of PTAs across all years. This would inflate instances of ExCESSive Bilateralism in earlier years given the increase in PTAs over time. I accordingly establish a time-varying threshold for PTA entry, taking the number of PTA formations in a given year as a proportion of the number of dyads in that year (e.g., $p=0.011$ on average for all states as in Model 7 in Table 40. This approach addresses the concern that both depth and under-prediction might be positively correlated with time, and that therefore the relationship between the two may be spurious. Using the baseline model for all states, this approach correctly predicts 4,539 of 6,898 (65.8\%) entries into a PTA, and identifies 2,359 of 6,898 (34.2\%) PTAs as 'excessive' ${ }^{44}$ In second-stage regressions I use ExCEssive BILATERALism to explain Agreement Depth. I exclude non-reciprocal agreements aimed at development assistance, such as the Lomé and Yaoundé agreements, but include plurilateral agreements (with more than two members) given the latter will still figure in negotiators' calculations.

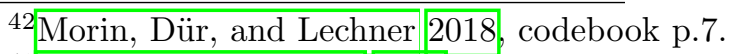

${ }^{43}$ Baier and Bergstrand 2004.

${ }^{44}$ See Table 6 in the appendix.
} 
As above, I expect that countries with a demonstrated interest in the systemic implications of global trade rules will be more likely to sequence agreements. I identify such countries through their justifications for participation in WTO disputes as a third party. I take advantage of the two justifications for third-party participation in WTO disputes provided for under WTO rules: having a substantial trade interest in a dispute, or an interest in the systemic implications of the case. Disputes attracting the latter justification often focus on relatively new or unsettled aspects of international trade law. As an illustration, disputes over anti-dumping measures (and U.S. practice in particular) have frequently attracted third parties with a strong systemic interest in the interpretation of the WTO's Antidumping Agreement 45 even if such states do not have a material interest in those disputes. Contrast this with disputes over EU regulations that limit trade in seal products (WTO dispute DS400), where a third country such as Iceland justified its participation based on material interest given its long tradition of sealing.

I count the number of times a country proclaims systemic interest in a dispute. The mean number of times a country cites systemic interest is 9.16; I code countries as STRONG SYSTEMIC if this value is above 9, and as Low SYSTEMIC otherwise. I also identify all EU states as Strong Systemic, since the EU acts as a unified actor in trade and the EU has as a whole cited systemic interest 75 times. I assume that countries' behaviour as third parties in WTO disputes reflects long-standing country dispositions and therefore is relatively time-invariant. Because it is possible that factors predicting PTA existence might differ systematically for these two groups of states, I identify excessive PTAs for each group separately, using the approach outlined above. A supermajority of third parties are in favour

\footnotetext{
${ }^{45}$ The Agreement on Implementation of Article VI of the General Agreement on Tariffs and Trade 1994.
} 
of the complainant in WTO disputes, alleviating concern that these states have an interest in limiting trade rather than liberalizing.

\subsection{Data}

The gravity dataset is constructed using annual import and export figures from the IMF's Direction of Trade Statistics (DOTS), which range from 1950 to 2015 ${ }^{46}$ For data on GDP, GDP per-capita and other country-level economic variables I use the World Development Indicators (WDI) from the World Bank 47 Distance and other geographic measures are from the CEPII database ${ }^{48}$ regime type is measured using Polity 4,49 and data on PTA depth and flexibility uses the Design of Trade Agreements (DESTA) dataset.50 I use two measures of flexibility provided for in the DESTA data: a measure of long-term flexibility capturing the presence of four possible escape clauses, and an additive measure capturing references to a range of sources of flexibility that collectively tell us about the 'rigidity' of the agreement's flexibility.

The DESTA data has both an 'Index' measure and a 'Rasch' measure of PTA depth. The Index variable counts the presence of substantive commitments in seven possible issueareas that may be included in the agreement. These include comprehensive tariff reductions (as opposed to partial scope agreements), and cooperation in non-tariff areas: services, investment, standards, public procurement, competition, and intellectual property rights. The Index measure ranges from 0 to 7 ; higher values indicate greater coverage. The Rasch

\footnotetext{
${ }^{46}$ http://data.imf.org/dot

${ }^{47}$ http://data.worldbank.org/data-catalog/world-development-indicators

48 Mayer and Zignago 2011.

${ }^{49}$ Marshall, Gurr, and Jaggers 2016.

50 Dür, Baccini, and Elsig 2014 Baccini, Dür, and Elsig 2015.
} 
variable is constructed using a Rasch model of latent trait analysis (factor analysis for binary data) on the presence or absence of 48 different variables related to the depth of an agreement, in issues such as services liberalization, standards, or trade-related investment measures. These different variables are assumed to relate to a single underlying dimension (depth of the PTA), and helps to address the concern that since cooperation on these different issues tends to be highly correlated, an additive measure may over-state the extent of depth in a given PTA. The resulting measure ranges from -1.728 to 1.885, with higher values indicating deeper cooperation.

Data on environmental norms is taken from the TRade \& ENvironment Database (TREND) ${ }^{51}$ Data on countries' alliances is from version 4.1 of the Correlates of War alliance data $\sqrt[52]{2}$ and data on disputes is from version 4.1 of the Militarized Interstate Disputes (MID) data, also from the Correlates of War project. ${ }^{53}$ I also include a measure of global economic business cycles, 54 measured by the year-to-year change in global economic output. Controls for bureaucratic attributes come from the Varieties of Democracy (V-Dem) project55 Data on participation in the WTO's dispute settlement system is retrieved from the WTO website 56

\footnotetext{
${ }^{51}$ Morin, Dür, and Lechner 2018

${ }^{52}$ Gibler 2009.

53 Palmer et al. 2015.

${ }^{54}$ Mansfield and Milner 2012, 75.

${ }^{55}$ Coppedge et al. 2019 .

${ }^{56}$ https : //www . wto.org.
} 


\section{Sequencing: quantitative evidence}

\subsection{Excessive bilateralism and agreement depth}

Models presented in Table 1 predict PTA entry. Model 1 predicts entry across all country pairs, while Model 2 excludes EU countries to address any concern that the results are strongly influenced by the EU. Results are similar between the base and non-EU models.

Table 1: Predicting entry into a Preferential Trade Agreement (base model)

\begin{tabular}{lcc}
\hline \hline & \multicolumn{2}{c}{ DV: PTA entry } \\
& $(1)$ & $(2)$ \\
& All states & No EU \\
\hline Distance (logged) & $-0.60^{* * *}$ & $-0.69^{* * *}$ \\
& $(0.02)$ & $(0.02)$ \\
GDP sum (logged, t-5) & $0.06^{* * *}$ & $0.06^{* * *}$ \\
& $(0.01)$ & $(0.01)$ \\
GDP difference (logged, t-5) & $-0.12^{* * *}$ & $-0.13^{* * *}$ \\
& $(0.01)$ & $(0.01)$ \\
Remoteness & $0.44^{* * *}$ & $1.10^{* * *}$ \\
& $(0.10)$ & $(0.12)$ \\
Same continent & $-2.29^{* * *}$ & $-7.85^{* * *}$ \\
& $(0.87)$ & $(1.04)$ \\
Polity scores (own) & $0.01^{* * *}$ & 0.00 \\
& $(0.00)$ & $(0.00)$ \\
Polity scores (partner) & $0.01^{* * *}$ & $0.00^{*}$ \\
& $(0.00)$ & $(0.00)$ \\
Both in GATT & $0.35^{* * *}$ & $0.49^{* * *}$ \\
& $(0.05)$ & $(0.05)$ \\
Both in WTO & $-0.17^{* * *}$ & $-0.55^{* * *}$ \\
& $(0.06)$ & $(0.07)$ \\
Year & 0.00 & $0.01^{* * *}$ \\
Constant & $(0.00)$ & $(0.00)$ \\
& -3.12 & $-17.83^{* * *}$ \\
\hline N & $(3.55)$ & $(3.87)$ \\
Plusters & 628,723 & 547,654 \\
Pseudo R-squared & 10,944 & 10,832 \\
\hline \hline & 0.14 & 0.15 \\
\hline
\end{tabular}

Cells contain logit regression estimates with robust standard errors clustered at the undirected dyad. Binary DV is PTA entry.

${ }^{*} p<0.10,{ }^{* *} p<0.05,{ }^{* * *} p<0.01$

I identify as 'excessive' those PTAs that are least well-predicted by these models. 
EXCESSIVE Bilateralism is the main explanatory variable in second-stage regressions presented in Table 2. The positive coefficient on this variable in column 1 shows that PTAs that are less well-predicted tend to have a higher depth score using DESTA's 'Rasch' measure as well as the 'Index' measure (column 2). Without the EU (column 3), excessive PTAs are even more strongly associated with increased depth.

Table 2: Excessive PTAs and Agreement Depth (Base model)

\begin{tabular}{lccc}
\hline \hline & \multicolumn{3}{c}{ DV: Agreement depth } \\
& $(1)$ & $(2)$ & $(3)$ \\
& Rasch measure & Index measure & Rasch measure \\
& & & No EU \\
\hline Excessive Bilateralism & $\mathbf{0 . 0 7}$ & $\mathbf{0 . 1 6}$ & $\mathbf{0 . 1 6}^{* * *}$ \\
& $(\mathbf{0 . 0 3})$ & $(\mathbf{0 . 0 7})$ & $(\mathbf{0 . 0 4})$ \\
Distance (logged) & 0.01 & $0.08^{* * *}$ & -0.01 \\
& $(0.01)$ & $(0.03)$ & $(0.01)$ \\
GDP sum (logged, t-5) & $0.04^{* * *}$ & $0.07^{* * *}$ & $0.05^{* * *}$ \\
& $(0.00)$ & $(0.01)$ & $(0.01)$ \\
GDP difference (logged, t-5) & $0.02^{* * *}$ & $0.09^{* * *}$ & $0.02^{* *}$ \\
& $(0.01)$ & $(0.01)$ & $(0.01)$ \\
Remoteness & $-0.77^{* * *}$ & $-1.40^{* * *}$ & $-0.50^{* * *}$ \\
& $(0.09)$ & $(0.19)$ & $(0.10)$ \\
Same continent & $6.31^{* * *}$ & $11.44^{* * *}$ & $4.09^{* * *}$ \\
Polity scores (own) & $(0.72)$ & $(1.59)$ & $(0.86)$ \\
Polity scores (partner) & $0.01^{*}$ & 0.00 & $0.01^{* *}$ \\
& $(0.00)$ & $(0.01)$ & $(0.00)$ \\
Both in GATT & $0.02^{* * *}$ & $0.04^{* * *}$ & $0.02^{* * *}$ \\
& $(0.00)$ & $(0.00)$ & $(0.00)$ \\
Both in WTO & -0.00 & $0.11^{* *}$ & 0.02 \\
& $(0.02)$ & $(0.05)$ & $(0.02)$ \\
Constant & $0.35^{* * *}$ & $0.56^{* * *}$ & $0.26^{* * *}$ \\
Country dummies & $(0.06)$ & $(0.11)$ & $(0.07)$ \\
Year dummies & $-3.18^{* * *}$ & $-3.87^{* * *}$ & $-3.34^{* * *}$ \\
\hline N & $(0.53)$ & $(0.76)$ & $(0.60)$ \\
R-squared & Yes & Yes & Yes \\
Clusters & Yes & Yes & Yes \\
\hline \hline
\end{tabular}

Cells contain OLS regression estimates with standard errors clustered at the undirected dyad in parentheses. DV is agreement depth (Rasch or Index measure). ${ }^{*} p<0.10,{ }^{* *} p<0.05,{ }^{* * *} p<0.01$

Table 3 shows that the main result in Model 1 of Table 2 is robust to a range of 
additional controls. I control for the design of previous PTAs as we may be concerned that PTA depth merely reflects previous PTA design and not an attempt to innovate. Thus, I include variables with the depth score of the deepest agreement previously signed by both countries in the dyad. I also control for PTA flexibility as this is associated with depth and could lead to omitted variable bias if excessive PTAs are simply more flexible. We may be concerned that countries with stronger (trade) bureaucracies are both more likely to sign many agreements (some of which are excessive) and also more likely to sign more ambitious agreements. As such, I control for the bureaucratic qualities of agreement parties in both first- and second-stage regressions. I find the expected positive relationship between these variables and PTA depth, but controlling for them does not affect the main finding that excessive PTAs are more ambitious than other agreements.

The results in Tables 2 and 3 provide good support for H1. Less well-predicted PTAs tend to be more ambitious. Turning to H2, Table 4 presents results from second-stage regressions in which I add further control variables and test the expectation about which countries are most likely to sequence agreements 57 I subset the sample of countries for the first- and second-stage regressions based on behavior in WTO disputes, as above. Columns 1-3 present results for states with the strongest revealed concern for global trade norms; columns 4-6 present results for states with weaker revealed concern for global trade norms, and column 7 uses data on countries' justifications in WTO disputes for an interaction model in which all countries are included.

The results support H2. I control for the political relationship between countries and the global geopolitical environment (change in Global GDP and the value of the largest

\footnotetext{
${ }^{57}$ First-stage regressions are presented in the appendix.
} 
Table 3: Excessive PTAs and Agreement Depth (additional controls)

\begin{tabular}{|c|c|}
\hline & DV: Agreement depth (Rasch) \\
\hline Excessive Bilateralism & $\begin{array}{l}0.07^{* * *} \\
(0.03)\end{array}$ \\
\hline Distance (logged) & $\begin{array}{c}-0.04^{* * *} \\
(0.01)\end{array}$ \\
\hline GDP sum (logged, t-5) & $\begin{array}{c}0.02^{* * *} \\
(0.00)\end{array}$ \\
\hline GDP difference (logged, t-5) & $\begin{array}{c}0.01 \\
(0.01)\end{array}$ \\
\hline Remoteness & $\begin{array}{c}-0.81^{* * *} \\
(0.08)\end{array}$ \\
\hline Same continent & $\begin{array}{c}6.83^{* * *} \\
(0.70)\end{array}$ \\
\hline Polity scores (own) & $\begin{array}{l}0.01^{* *} \\
(0.00)\end{array}$ \\
\hline Polity scores (partner) & $\begin{array}{c}0.02^{* * *} \\
(0.00)\end{array}$ \\
\hline Both in GATT & $\begin{array}{l}-0.01 \\
(0.02)\end{array}$ \\
\hline Both in WTO & $\begin{array}{c}0.24^{* * *} \\
(0.06)\end{array}$ \\
\hline Previous highest PTA depth (own) & $\begin{array}{c}0.12^{* * *} \\
(0.02)\end{array}$ \\
\hline Previous highest PTA depth (partner) & $\begin{array}{c}0.24^{* * *} \\
(0.01)\end{array}$ \\
\hline PTA flexibility (additive measure) & $\begin{array}{c}0.13^{* * *} \\
(0.01)\end{array}$ \\
\hline PTA flexibility (long-term) & $\begin{array}{c}0.17^{* * *} \\
(0.01)\end{array}$ \\
\hline Bureaucratic recruitment criteria (own) & $\begin{array}{l}0.04^{*} \\
(0.02)\end{array}$ \\
\hline Bureaucratic remuneration (own) & $\begin{array}{c}0.07 \\
(0.06)\end{array}$ \\
\hline Bureaucratic recruitment criteria (partner) & $\begin{array}{c}0.03^{* * *} \\
(0.01)\end{array}$ \\
\hline Bureaucratic remuneration (partner) & $\begin{array}{c}0.07^{* * *} \\
(0.01)\end{array}$ \\
\hline Constant & $\begin{array}{c}-2.84^{* * *} \\
(0.21)\end{array}$ \\
\hline Country dummies & Yes \\
\hline Year dummies & Yes \\
\hline $\mathrm{N}$ & 5451 \\
\hline R-squared & 0.92 \\
\hline Clusters & 1971 \\
\hline
\end{tabular}

Cells contain OLS regression estimates with standard errors clustered at the undirected dyad in parentheses. DV is the Rasch measure of agreement depth. ${ }^{*} p<0.10,{ }^{* *} p<0.05,{ }^{* * *} p<0.01$ 
Table 4: Excessive bilateralism and agreement depth: full specification

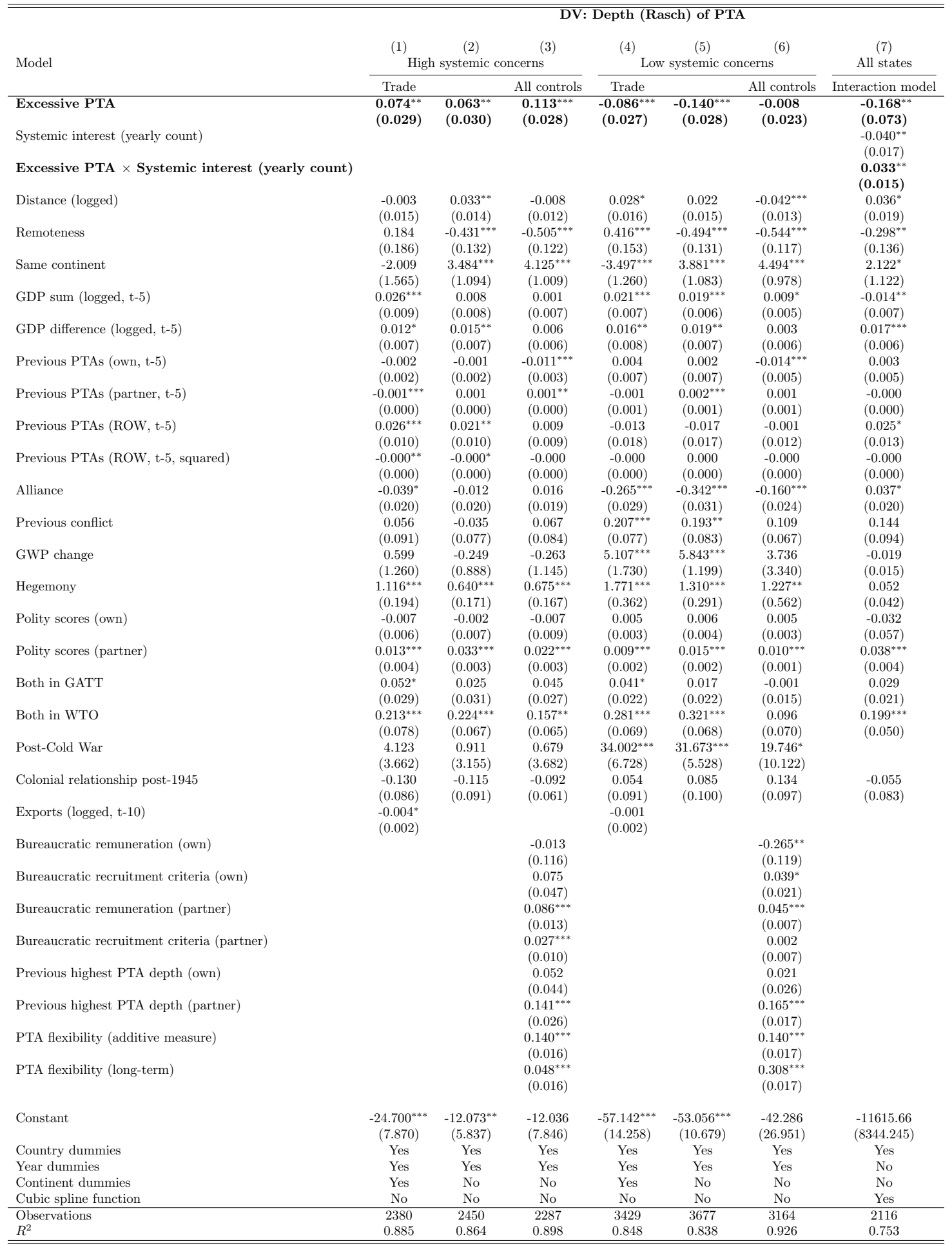

Cells contain OLS regression estimates with standard errors clustered at the undirected dyad in parentheses. DV is agreement depth (Rasch measure). ${ }^{*} p<0.10,{ }^{* *} p<0.05,{ }^{* * *} p<0.01$ 
economy in the world) 58 I also control for the number of PTAs signed by each partner, and the total number of PTAs signed by all states (and its square). ${ }^{59}$ In columns 1 and 4, I include 10-year lagged exports to account for deviations from natural trading partner patters. I omit the export variable in columns 2 and 5, but retain the other controls. In column 3 and 6 I add all of the extra controls from Table 3. Across these specifications, I find that countries that demonstrate stronger concern for the systemic implications of trade rules sign ambitious agreements with under-predicted partners, while the opposite tends to hold true for other countries.

This finding is further supported when using an interaction model and the full sample of countries. In Column 7, the model interacts 'excessive' PTAs with the raw count of the annual number of countries' appeals to the systemic implications of a given WTO dispute as the justification for their participation. We can see that as countries cite systemic interest more frequently in WTO disputes, the 'excessive' PTAs that they sign are more likely to be deeper than other agreements. Strategic behavior during trade negotiations is likely to be associated with a concern for the way that global trade norms evolve.

As the results presented in Table 4 are OLS regression estimates, we can interpret the coefficients directly. In Models 2 and 5, 'excessive' agreements are, all else equal, 0.063 deeper for countries with strong systemic concerns, and 0.14 shallower for countries with weak systemic concerns, using DESTA's 'Rasch' measure of depth. The Rasch measure of PTA depth ranges from -1.73 to 1.89 , with a standard deviation of 0.982 . While the substantive impact of this result is not huge, the difference between the two groups of states

\footnotetext{
${ }^{58}$ Mansfield and Milner 2012.

${ }^{59}$ Baier, Bergstrand, and Mariutto 2014
} 
is striking. The effect is even stronger when adding the additional controls (Models 3 and 6). Here we see that those countries with a keener interest in the systemic implications of global trade norms sign 'excessive' agreements that are on average deeper by 0.113 on DESTA's 'Rasch' measure.

\subsection{With whom do states innovate?}

Turning to the TREND data, I expect states should be more likely to innovate in 'excessive' trade agreements. Table 5 tests this expectation, using similar specifications to the base model from Table 2[60 Excessive agreements are clearly associated with greater innovation in the area of environmental norms. An excessive agreement has on average $3 \%$ more innovative content in the area of environmental norms than well-predicted agreements (column 2), amounting to around $2.3(\exp (0.84))$ more innovative norms than a well-predicted agreement (column 4). Once again those agreements that are less well predicted by the economic and political factors usually deemed important for trade agreements are, counter-intuitively, a significant source of innovation in the trade regime.

The quantitative evidence supports the two hypotheses presented above. Agreements that are not well predicted by the economic and political relationship between their members are more ambitious in scope than better-predicted agreements (H1), and the positive relationship between low-prediction and high-ambition of agreements will be stronger for countries that demonstrate the greatest concern for the legal norms of the global trade regime (H2). The following section looks for evidence of sequencing in the record of individual countries.

\footnotetext{
${ }^{60}$ The results from a negative binomial regression (available on request) are substantively the same.
} 
Table 5: Excessive PTAs and Environmental Innovation

\begin{tabular}{|c|c|c|c|c|}
\hline \multirow[b]{4}{*}{ Excessive Bilateralism } & \multicolumn{4}{|c|}{ DV: Innovation in environmental norms } \\
\hline & (1) & $(2)$ & $(3)$ & $(4)$ \\
\hline & \multicolumn{2}{|c|}{$\begin{array}{l}\text { Proportion } \\
\text { (OLS) }\end{array}$} & \multicolumn{2}{|c|}{$\begin{array}{l}\text { Sum innovative norms } \\
\text { (Poisson regression) }\end{array}$} \\
\hline & $\begin{array}{l}\mathbf{0 . 0 1}^{* *} \\
(0.00)\end{array}$ & $\begin{array}{l}0.03^{* * *} \\
(0.00)\end{array}$ & $\begin{array}{l}0.55^{* * *} \\
(0.07)\end{array}$ & $\begin{array}{l}0.84^{* * *} \\
(0.09)\end{array}$ \\
\hline Distance (logged) & $\begin{array}{c}0.00 \\
(0.00)\end{array}$ & $\begin{array}{c}0.01^{* * *} \\
(0.00)\end{array}$ & $\begin{array}{c}0.24^{* * *} \\
(0.05)\end{array}$ & $\begin{array}{c}0.28^{* * *} \\
(0.06)\end{array}$ \\
\hline GDP sum (logged, t-5) & $\begin{array}{l}0.00 \\
(0.00)\end{array}$ & $\begin{array}{c}-0.00^{* * *} \\
(0.00)\end{array}$ & $\begin{array}{c}0.08^{* * *} \\
(0.03)\end{array}$ & $\begin{array}{l}-0.00 \\
(0.03)\end{array}$ \\
\hline GDP difference (logged, t-5) & $\begin{array}{l}-0.00 \\
(0.00)\end{array}$ & $\begin{array}{c}0.00 \\
(0.00)\end{array}$ & $\begin{array}{c}0.04^{* * *} \\
(0.02)\end{array}$ & $\begin{array}{l}0.03^{*} \\
(0.02)\end{array}$ \\
\hline Remoteness & $\begin{array}{c}-0.02^{* *} \\
(0.01)\end{array}$ & $\begin{array}{c}-0.07^{* * *} \\
(0.01)\end{array}$ & $\begin{array}{l}-0.19 \\
(0.46)\end{array}$ & $\begin{array}{l}-0.58 \\
(0.37)\end{array}$ \\
\hline Same continent & $\begin{array}{c}0.20^{* * *} \\
(0.07)\end{array}$ & $\begin{array}{c}0.65^{* * *} \\
(0.07)\end{array}$ & $\begin{array}{l}1.26 \\
(3.80)\end{array}$ & $\begin{array}{l}5.04^{*} \\
(3.05)\end{array}$ \\
\hline Polity scores (own) & $\begin{array}{c}-0.00^{* * *} \\
(0.00)\end{array}$ & $\begin{array}{c}-0.00^{* * *} \\
(0.00)\end{array}$ & $\begin{array}{l}-0.00 \\
(0.01)\end{array}$ & $\begin{array}{c}0.02^{* * *} \\
(0.00)\end{array}$ \\
\hline Polity scores (partner) & $\begin{array}{c}-0.00^{* * *} \\
(0.00)\end{array}$ & $\begin{array}{c}-0.00^{* *} \\
(0.00)\end{array}$ & $\begin{array}{c}0.02^{* * *} \\
(0.00)\end{array}$ & $\begin{array}{c}0.02^{* * *} \\
(0.00)\end{array}$ \\
\hline Both in GATT & $\begin{array}{c}0.01 \\
(0.00)\end{array}$ & $\begin{array}{c}0.03^{* * *} \\
(0.00)\end{array}$ & $\begin{array}{c}0.46^{* * *} \\
(0.05)\end{array}$ & $\begin{array}{c}0.66^{* * *} \\
(0.06)\end{array}$ \\
\hline Both in WTO & $\begin{array}{l}0.01 \\
(0.01)\end{array}$ & $\begin{array}{c}-0.02^{* *} \\
(0.01)\end{array}$ & $\begin{array}{c}-1.84^{* * *} \\
(0.14)\end{array}$ & $\begin{array}{c}-1.68^{* * *} \\
(0.13)\end{array}$ \\
\hline Year & & $\begin{array}{c}-0.00^{* * *} \\
(0.00)\end{array}$ & $\begin{array}{c}0.03^{* * *} \\
(0.01)\end{array}$ & $\begin{array}{c}0.03^{* * *} \\
(0.00)\end{array}$ \\
\hline Constant & $\begin{array}{l}0.00 \\
(0.03)\end{array}$ & $\begin{array}{c}4.34^{* * *} \\
(0.72)\end{array}$ & $\begin{array}{c}-57.73^{* * *} \\
(9.89)\end{array}$ & $\begin{array}{c}-66.13^{* * *} \\
(8.60)\end{array}$ \\
\hline Country dummies & Yes & No & Yes & No \\
\hline Year dummies & Yes & No & No & No \\
\hline$\overline{\mathrm{N}}$ & 6772 & 6772 & 6772 & 6772 \\
\hline R-squared & 0.68 & 0.24 & & \\
\hline Prob $>$ Chi2 & & & 0.0000 & 0.0000 \\
\hline Clusters & 2224 & 2224 & 2224 & 2224 \\
\hline
\end{tabular}

Cells contain OLS regression estimates (columns 1 and 2) and Poisson regression estimates (columns 3 and 4) with standard errors clustered at the undirected dyad in parentheses. DV is the presence of novel environmental norms in the PTA, measured as a proportion of total environmental norms (columns 1 and 2 ) and as a count of novel norms (columns 3 and 4 ). ${ }^{*} p<0.10,{ }^{* *} p<0.05,{ }^{* * *} p<0.01$ 


\section{Qualitative evidence: New Zealand and Post-Brexit UK}

Qualitative probes from New Zealand and from the Post-Brexit United Kingdom reveal further evidence that countries sequence to establish precedent strategically. Strategic intent is difficult to discern, and the confidential nature of trade negotiations also means that we cannot easily observe (or report on) how negotiators navigate the precedent of previous agreements. We can however observe how negotiators seek public input on prospective agreements and how they justify their actions during the ratification process. Accordingly, I make use of official documents from trade departments and ministries, as well as testimony from officials to parliamentarians.

I expect policymakers to make more justificatory references to the precedent-setting value of an agreement prior to and during negotiations with smaller or less-important partners, as compared to negotiations with more economically important partners. Evidence of such justifications would support the argument that negotiators are strategic in their effort to set precedent while negotiating with less important partners. We should also observe agreements with smaller or less important partners establishing new norms or initiating trade policy shifts (as per H1). This would indicate that strategic rhetoric is not empty; negotiations with less important partners are indeed used to set precedent.

The evidence supports these expectations. New Zealand has openly sought to establish model agreements with 'likeminded' but economically less-important partners (notably Singapore and Chile), in an effort to influence the evolution of trade rules in the Asia-Pacific and beyond. Officials from New Zealand's Ministry of Foreign Affairs and Trade explicitly 
invoke the strategic precedent-setting potential of agreements that have little immediate economic benefit. Discussion documents from the UK Department for International Trade (DIT) justifies negotiations with smaller partners (Australia and New Zealand) on the basis of establishing precedent, while such justification is missing from similar discussion documents relating to negotiations with more important partners (the EU, the US, and Japan).

How should we evaluate this evidence from a methodological perspective? Looking to New Zealand, I examine the overall trajectory of negotiations to illustrate the intuition of the argument as a 'plausibility probe' 61 Taken as a whole, New Zealand may be viewed as a typical case. Wellington has a demonstrable interest in the evolution of global trade rules as well as experienced trade negotiators. Yet as a small export-oriented country with few trade barriers, it lacks negotiating power. New Zealand also faces greater constraints on its trade negotiating resources than larger states; it can less afford to expend resources on negotiations where the economic or political justification is not compelling. The New Zealand evidence supports the theory, and also undermines a potential counter-argument that it is only powerful states that would seek to sequence agreements.

Following its departure from the EU, the need for the UK to rapidly negotiate numerous agreements without any recent negotiating precedent of its own provides an opportunity to adopt a 'most similar' design to test the relationship between the economic importance of partners and justificatory references to useful precedent. Variables relating to the UK (including negotiating context, the bureaucracy, and Government), as well as those relating to the wider global context (including the Covid-19 pandemic and the geopolitical context) are constant, with variation constrained to the economic importance of partners (the inde\begin{tabular}{l|l|l|}
${ }^{61}$ Levy & 2008. \\
\hline
\end{tabular} 
pendent variable) and the justificatory references to precedent (the dependent variable). The 'most similar' design used with the UK cases provides strong support for the argument ${ }^{2}$

\subsection{New Zealand: promoting liberalisation from the bottom up}

New Zealand has been an ardent supporter of multilateral liberalization through the GATT and the WTO. With the failure to meaningfully liberalize agricultural products during the Tokyo and Uruguay Rounds of multilateral negotiations however, New Zealand's trade policymakers pragmatically turned to bilateral and regional negotiations. This policy shift began with the Australia New Zealand Closer Economic Relations Trade Agreement (ANZCERTA or CER) in 1983 and its expansion through successive reviews ${ }^{63}$ and was formalized with the Ministry of Foreign Affairs and Trade (MFAT)'s 1993 publication of a trade strategy outlining multilateralism, regionalism, bilateralism and unilateralism as complementary approaches to adopt liberal reforms domestically, and to promote liberalization internationally 64 By the late 1990s and early 2000s, this strategy found its expression in a series of negotiations. An agreement with Singapore-New Zealand's second bilateral Free Trade Agreement, and Singapore's first-was negotiated between 1999 and 2000. Wellington subsequently launched negotiations with other partners in the Asia-Pacific.

New Zealand has PTAs in force with Thailand (2005), Chile and Brunei under the P4 agreement (2006), China (2008), Malaysia (2010), ASEAN (negotiated jointly with Australia; 2012), South Korea (2015), the Separate Customs Territory of Taiwan, Penghu, Kinmen and Matsu (2013), and with members of the (CP)TPP (2018). New Zealand launched negotia-

\footnotetext{
${ }^{62}$ Seawright and Gerring 2008 .

${ }^{63}$ Castle, Le Quesne, and Leslie 2016, 50

${ }^{64}$ New Zealand MFAT 1993 ; Leslie |2015.
} 
tions with the EU in June 2018, with the UK in June 2020, and remains in other negotiations including with Pacific Alliance countries. New Zealand recently concluded negotiation of the 16-member Regional Comprehensive Economic Partnership (RCEP) in November 2020, and of the Digital Economy Partnership Agreement (DEPA) with Singapore and Chile (2020) ${ }^{65}$

New Zealand has strategically signed agreements with similarly market-liberal countries in an often explicit effort to influence the evolution of subsequent trade norms. New Zealand's most senior trade official Vangelis Vitalis describes the strategy as a "a non-linear, evolving 'stepping stones' or 'building blocks' strategy that carefully cultivates and supports the evolving regional economic architecture" ${ }^{66}$ As Leslie explains, New Zealand policymakers have found 'like-minded' partners in successive Australian and Singaporean governments; New Zealand and Singaporean officials similarly found partners in the Chilean government for the negotiation of the $\mathrm{P} 4$ agreement ${ }^{67}$

Both of the empirical expectations outlined above are borne out in the evidence from New Zealand. An emphasis on the strategic establishment of 'models' of cooperation has featured strongly in the rationale for key negotiations with smaller partners (especially Singapore and Chile). The 2001 Closer Economic Partnership (CEP) with Singapore, then only the 17th export market for New Zealand and the 12th most important source of imports 68 was envisaged explicitly as a model for further liberalization in the Asia-Pacific. An internal New Zealand MFAT paper authored by Tim Groser (destined to become Trade Minister) noted that "there are likely to be few discernible trade benefits... the case for such a FTA is

\footnotetext{
${ }^{65}$ See https://www.mfat.govt.nz/en/trade/free-trade-agreements/

66 Vitalis 2015.

${ }^{67}$ Leslie 2015, 18-20.

${ }^{68}$ Hoadley 2017, ch. 6 .
} 
almost wholly strategic." 69 According to Ministerial testimony to the New Zealand Parliament, there were no illusions about the low economic benefits of a New Zealand-Singapore FTA, but an agreement was seen as a way to "get the ball rolling" on liberalization in the Asia-Pacific 70

The aim of creating a model echoes through the P4 agreement: discussing the CPTPP, MFAT's National Interest Analysis notes that "One of the objectives of the P4 was to create a model agreement that could potentially attract new Asia-Pacific members and be a building block for regional economic integration."71 Officials' oral testimony to the New Zealand Parliament makes clear how, over the course of two decades, negotiators sought to build on the norm of "open regionalism" and WTO-consistency embraced in the 1990s. Vitalis draws a clear link from the agreement with Singapore, through the "commercially not important" P4 agreement with Singapore, Chile and Brunei, and on to the (CP)TPP, for which previous agreements acted as a "paving stone" and a "signal" 72

The testimony and analysis on the 2020 DEPA is perhaps even more telling. The agreement reinforces existing commitments (for instance in the CPTPP), and illustrates how New Zealand has used an agreement with little immediate economic rationale to promote novel norms. MFAT explains the goals of DEPA are to "[c]o-create and shape global norms for digital trade"; "[c]reate a model digital economy agreement that can act as a pathfinder for others, raising ambition in other contexts and forums..."; and to "[b]uild confidence on new economy issues..." ${ }^{73}$ The authors of the National Interest Analysis acknowledge

\footnotetext{
${ }^{69}$ Cited in Hoadley 2017, ch. 6.

${ }^{70}$ Hon Lockwood Smith, cited in Hoadley 2017, ch. 6, fn. 3.

71 New Zealand MFAT 2018, 19

$72 \overline{\text { Vitalis } 2018}$

${ }^{73}$ New Zealand MFAT $2020,5$.
} 
that a further commitment to current regulatory settings carries some possible cost in lost policy space ${ }^{74}$ but justifies this not with reference to any gains from the agreement with current signatories (which it accepts are minimal) but on the grounds of promoting desired regulatory norms. As the report makes explicit, the "DEPA is a pathfinder agreement which enables New Zealand and our likeminded partners to shape global norms for digital trade"; the agreement sets a "precedent for other frameworks" in particular issue-areas 75 Members of New Zealand's Parliamentary Economic Development, Science and Innovation Committee report that they queried MFAT about the rationale for the agreement given it did not require legislative changes in New Zealand, and note that MFAT's response was that DEPA "would take New Zealand further than existing measures, and provide a strategic framework."[76 Thinking back to the strategic model presented in Figure 1, DEPA illustrates NZ efforts to shift its reservation value closer to its idealpoint by establishing a further negotiating precedent. In doing so, officials have sought to justify agreements with little immediate economic benefit on the basis of their precedential value.

\subsection{The United Kingdom}

In looking to the UK, I exploit the shock of the successful 'Leave' vote in the 2016 referendum on the UK's membership in the EU. Within the EU, trade policy is an 'exclusive EU competence', meaning that trade policy is formulated by the EU as a whole on behalf of member states.77 Member states have relatively little independent trade policy expertise, as the Directorate General for Trade (DG Trade) conducts negotiations with third-parties,

\footnotetext{
${ }^{74}$ New Zealand MFAT $2020,5$.

75 New Zealand MFAT 2020, 7,13.

${ }^{76}$ Young 2020, 3.

77 Art. 207 of the Treaty on the Functioning of the European Union, TFEU.
} 
with the support of other DGs for certain issues. On leaving the EU, the UK will trade on WTO terms with other countries, as it will no longer be covered by EU agreements. This places UK exporters at a considerable disadvantage with their competitors from other countries, as UK exports will face tariffs in foreign markets. Because of Brexit, the UK has had to rapidly establish its own trade policy and bureaucracy to address this challenge. The unexpected success of the 'Leave' vote in the Brexit referendum makes for an ideal test-case for the argument as it provides us with a scenario in which we can observe how policymakers design new policy following an unexpected political shock ${ }^{78}$ How are UK trade negotiators choosing PTA partners, and how is this choice being justified given scarce bureaucratic resources? How are UK policymakers seeking to address the challenge of advancing UK trade interests?

The need for the UK to negotiate a number of agreements quickly allows us to compare the language used in discussion documents for different negotiations while holding other variables constant. I expect negotiations with smaller states to be justified on the basis of setting precedent, while I have no such expectation about negotiations with more important trade partners. This is indeed what we see when we look to the discussion documents that the UK's DIT has published on prospective PTA negotiations. When the DIT unveiled its postBrexit trade policy, it identified five partners that the UK is prioritising for PTA negotiations: the EU, the US, Japan, Australia, and New Zealand 79 Of these five partners, the EU, the US, and Japan account for a sizeable proportion of UK trade. The EU is by far the UK's largest trading partner (47\% of the UK's trade); the US is the largest non-EU trading partner, and

\footnotetext{
${ }^{78}$ Diamond, Nedergaard, and Rosamond 2018, 3.

${ }^{79}$ https://www.gov.uk/government/collections/the-uks-trade-agreements
} 
Japan the UK's fourth-largest non-EU partner (11th total if including EU member states individually). Australia and New Zealand are far less economically important. Australia is the UK's 11th largest non-EU trading partner (20th total), while New Zealand ranks 34th (53rd total).

What explains the prominence of Australia and New Zealand on the short-list of priority trade negotiating partners for the post-Brexit UK? These are two countries with whom the UK shares close political and cultural ties, but which account for a relatively small proportion of the UK's trade. The UK's DIT has released strategy documents outlining the rationale for each of these negotiations 80 While all of these documents emphasize the potential for an agreement to boost trade and investment between signatories, only the agreements with Australia and New Zealand also appear motivated by establishing a precedent for future negotiations: "An FTA with New Zealand would be an opportunity to set an ambitious precedent for future agreements ..." 81 "We will seek to set a new precedent with Australia by establishing an ambitious framework for co-operation in these areas [of technology, innovation and research and development]..." 82

Indeed, it was widely put out that PTA negotiations with New Zealand would be likely to be completed rapidly and would enable the UK to establish a template to be used in future negotiations. Absent such a template, the UK would be less likely to secure its interests in negotiations with other (more powerful) counterparts. In outlining the UK Government's priorities in Parliament, the Trade Secretary Liam Fox was quite clear that "[a]n FTA with New Zealand would be an opportunity to set an ambitious precedent" and

\footnotetext{
${ }^{80}$ UK DIT 2020a $b c d e$

${ }^{81}$ UK DIT 2020d.

$82 \overline{\text { UK DIT } 2020 b}$.
} 
to "pioneer modern and enduring trade rules" 83 the UK Government has repeated this rationale for an FTA with New Zealand in documents summarising public consultation 84

\section{Conclusion}

Trade has become one of the most politically salient issues in contemporary international politics. How do negotiators regulate contested issue-areas? How do they introduce innovations in trade law? How does the trade regime evolve? I argue that trade policymakers and negotiators take the future into account during their negotiations. I first present a theory of PTA sequencing. Building on insights from historical institutionalism and negotiation theory, I argue that the power of precedent in agreement design and the 'stickiness' of legal language creates incentives for states to strategically sign innovative agreements in easier negotiations in order to increase the odds of achieving their ideal outcome in subsequent negotiations. This leads to the hypothesis that those PTAs that are less well predicted by economic factors should, paradoxically, be more ambitious, and should be a site of normative innovation.

This hypothesis is borne out in the evidence that I present. As predicted by a theory of sequencing in which the main objective is to influence the legal content of the trade regime writ large, the results are strongest for precisely those states that have demonstrated the greatest interest in the systemic implications of global trade rules, as measured by their participation as third parties in WTO disputes. Turning to the topical area of environmental norms, I also show that innovation is most likely with under-predicted partners.

${ }^{83}$ UK House of Commons 2019, 6130.

${ }^{84}$ UK DIT 2019, 5. 
Recent negotiations involving New Zealand and the UK provide further evidence of negotiators' attempts to set and exploit precedent during trade negotiations. New Zealand officials have negotiated agreements with little economic rationale with the express purpose of codifying desired regulatory norms. By sequencing negotiations, UK negotiators may hope to establish preferred trade norms, improving their negotiating position in future interactions with later, more challenging partners.

While I focus on the context of international trade negotiations, the findings also contribute to the wider literature on path-dependence and precedent in political science, international relations, and other areas of social science. The initiation of a 'step on the path' is relatively under-theorised in this literature, which tends to rely on the notion of historical accidents or exogenous shocks at critical junctures in explaining the emergence of influential policy 85 This is one reason that path-dependencies are often associated with the persistence of inefficient or suboptimal outcomes or policies ${ }^{86}$ The present theory endogenizes path-dependencies into the design of legal rules (rather than the inverse): policymakers may sometimes bet on their actions establishing a (favourable) path-dependence that they consider to be optimal 87 One implication of this theoretical move is to create a potential bridge between historical institutionalist and 'functionalist' or rational choice approaches to studies of institutions and policy. Pierson suggests for instance that 'increasing returns arguments... provide a plausible counter to functionalist explanations in political science' 88 Viewing sequencing as a strategic rather than accidental process allows us to reconsider how rationalist/functionalist approaches and historical institutionalist approaches may be

\footnotetext{
${ }^{85}$ Pierson 2000.

${ }^{86}$ North 1990 Torfing 2009

${ }^{87}$ Similarly, see Pelc 2014.

${ }^{88}$ Pierson 2000, 263.
} 
integrated in a broader temporal context.

Finally, this article has not evaluated sequencing from a normative perspective, but the theory does have normative implications. Firstly, the evidence presented above suggests that those states that are most likely to sequence agreements are states that not only have a concern for the content of global trade rules, but also the ability to translate that concern into action. The existence of the current multilateral system is generally seen to benefit less powerful states, as it reduces the role of power in cooperative outcomes ${ }^{89}$ Yet the resulting system has hardly put states on an equal footing. The strategic exploitation of precedent in the WTO's case law appears to be the preserve of wealthy countries that have the legal expertise and resources to advance cases strategically 90 It appears that states that have greater legal capacity are also more likely to sequence trade agreements. This would suggest that sequencing may have distributional consequences: wealthier states with developed trade bureaucracies are more likely to see their preferred agreement design taken up by the wider membership of the international trade and investment regime.

It is also worth reflecting on how political contestation over trade agreements may be evolving. As negotiators' time horizons shift, so too do those of domestic groups likely to mobilize around trade. Inevitably though, the capacity of societal groups to anticipate future developments will be unequally distributed. This raises further normative concerns around the (in-)ability of under-resourced groups to have their voice heard in debates over trade policy. While precedent may help negotiators in later agreements, domestic actors are not dupes. The public backlash against new trade issues suggests that even as precedent

\footnotetext{
${ }^{89}$ Ikenberry 2001

${ }^{90}$ Pelc 2014.
} 
arms policymakers and officials for future negotiations, the potential for precedent-setting creates new cause for political mobilization. 


\section{References}

Allee, Todd, and Andrew Lugg. 2016. Who Wrote the Rules for the Trans-Pacific Partnership? Research 8 Politics 3 (3):1-9.

Allee, Todd, and Manfred Elsig. 2019. Are the Contents of International Treaties Copied and Pasted? Evidence from Preferential Trade Agreements. International Studies Quarterly 63(07):603-613.

Alschner, Wolfgang, and Dmitriy Skougarevskiy. 2015. Consistency and Legal Innovation in the BIT Universe. Working Paper 2595288. Stanford, C.A.: Stanford Public Law, Stanford University.

Alter, Karen J., and Sophie Meunier. 2009. The Politics of International Regime Complexity. Perspectives on Politics 7 (1):13-24.

Baccini, Leonardo, Andreas Dür, and Manfred Elsig. 2015. The Politics of Trade Agreement Design: Revisiting the Depth-Flexibility Nexus. International Studies Quarterly $59(12): 765-775$.

Baier, Scott L., and Jeffrey H. Bergstrand. 2004. Economic Determinants of Free Trade Agreements. Journal of International Economics 64 (1):29-63.

Baier, Scott L., Jeffrey H. Bergstrand, and Ronald Mariutto. 2014. Economic Determinants of Free Trade Agreements Revisited: Distinguishing Sources of Interdependence. Review of International Economics 22 (1):31-58. 
Baldwin, Richard. 2012. Sequencing Asian Regionalism: Theory and Lessons from Europe. Journal of Economic Integration 27 (1):1-32.

Bergsten, C. Fred. 2017. Currency Manipulation in the NAFTA Renegotiation. Peterson Institute for International Economics Trade Investment Policy Watch May 19.

Castle, Matthew, and Krzysztof J. Pelc. 2019. The Causes and Effects of Leaks in International Negotiations. International Studies Quarterly 63 (4):1147-1162.

Castle, Matthew, Simon Le Quesne, and John Leslie. 2016. Divergent Paths of State-Society Relations in European and Trans-Tasman Economic Integration. Journal of European Integration 38 (1):41-59.

Coppedge, Michael, John Gerring, Carl Henrik Knutsen, Staffan I. Lindberg, Jan Teorell, David Altman, Michael Bernhard, M. Steven Fish, Adam Glynn, Allen Hicken, Anna Lührmann, Kyle L. Marquardt, Kelly McMann, Pamela Paxton, Daniel Pemstein, Brigitte Seim, Rachel Sigman, Svend-Erik Skaaning, Jeffrey Staton, Steven Wilson, Agnes Cornell, Lisa Gastaldi, Haakon Gjerløw, Nina Ilchenko, Joshua Krusell, Laura Maxwell, Valeriya Mechkova, Juraj Medzihorsky, Josefine Pernes, Johannes von Römer, Natalia Stepanova, Aksel Sundström, Eitan Tzelgov, Yi ting Wang, Tore Wig, and Daniel Ziblatt. 2019. VDem [Country-Year/Country-Date] Dataset v9. Varieties of Democracy (V-Dem) Project

Crump, Larry. 2007. A Temporal Model of Negotiation Linkage Dynamics. Negotiation Journal 23 (2):117-153. 
Crump, Larry. 2016. Toward a Theory of Negotiation Precedent. Negotiation Journal 32 (2):85-102.

Crump, Larry, and Don Moon. 2017. Precedents in Negotiated Decisions: Korea-Australia Free Trade Agreement Negotiations. Negotiation Journal 33 (2):101-127.

De Bièvre, Dirk. 2018. The Paradox of Weakness in European Trade Policy: Contestation and Resilience in CETA and TTIP Negotiations. The International Spectator 53 (3):70-85.

Diamond, Patrick, Peter Nedergaard, and Ben Rosamond. 2018. Introduction. In The Routledge Handbook of the Politics of Brexit, edited by Peter Nedergaard Patrick Diamond, and Ben Rosamond. Milton Park: Routledge.

Dür, Andreas, Leonardo Baccini, and Manfred Elsig. 2014. The Design of International Trade Agreements: Introducing a New Dataset. Review of International Organizations 9 (3):353-375.

Gibler, Douglas M. 2009. International military alliances, 1648-2008. CQ Press.

Hoadley, Stephen. 2017. New Zealand Trade Negotiations. Wellington: New Zealand Institute of International Affairs.

Ikenberry, G. John. 2001. After Victory: Institutions, Strategic Restraint, and the Rebuilding of Order after Major Wars. Princeton, N.J.: Princeton University Press.

Lechner, Lisa. 2016. The Domestic Battle over the Design of Non-Trade Issues in Preferential Trade Agreements. Review of International Political Economy 23 (5):840-871. 
Leslie, John. 2015. New Zealand Trade Strategy and Evolving Asia-Pacific Regional Economic Architecture. Wellington: Asia New Zealand Foundation.

Levy, Jack S. 2008. Case Studies: Types, Designs, and Logics of Inference. Conflict Management and Peace Science 25 (1):1-18.

Mahoney, James, and Dietrich Rueschemeyer. 2003. Comparative Historical Analysis in the Social Sciences. Cambridge, U.K.; New York: Cambridge University Press.

Mansfield, Edward D., and Helen V. Milner. 2012. Votes, Vetoes and the Political Economy of International Trade Agreements. Princeton: Princeton University Press.

Mansfield, Edward D., Helen V. Milner, and B. Peter Rosendorff. 2002. Why Democracies Cooperate More: Electoral Control and International Trade Agreements. International Organization 56 (3):477-514.

Marshall, Monty G., Ted Robert Gurr, and Keith Jaggers. 2016. POLITY IV Project: Political Regime Characteristics and Transitions, 1800-2015. Dataset users' manual. Center for Systemic Peace.

Mattli, Walter. 1999. The Logic of Regional Integration: Europe and Beyond. Cambridge: Cambridge University Press.

Mayer, Thierry, and Soledad Zignago. 2011. Notes on CEPII's distances measures: The GeoDist database. Working Papers 2011-25. Paris: CEPII.

Meunier, Sophie, and Jean-Frédéric Morin. 2015. No Agreement is an Island: Negotiating TTIP in a Dense Regime Complex. In The Politics of Transatlantic Trade Negotiations: 
TTIP in a Globalized World, edited by Jean-Frédéric Morin, Tereza Novotna, Frederik Ponjaert, and Mario Telò , 196-209. London: Routledge.

Milewicz, Karolina, James Hollway, Claire Peacock, and Duncan Snidal. 2016. Beyond Trade: The Expanding Scope of the Nontrade Agenda in Trade Agreements. Journal of Conflict Resolution 62 (4):743-773.

Morin, Jean-Frédéric, and Edward Richard Gold. 2014. An Integrated Model of Legal Transplantation: The Diffusion of Intellectual Property Law in Developing Countries. International Studies Quarterly 58 (4):781-792.

Morin, Jean-Frédéric, Andreas Dür, and Lisa Lechner. 2018. Mapping the Trade and Environment Nexus: Insights from a New Data Set. Global Environmental Politics 18(2020/09/06):122-139.

Morin, Jean-Frédéric, Joost Pauwelyn, and James Hollway. 2017. The Trade Regime as a Complex Adaptive System: Exploration and Exploitation of Environmental Norms in Trade Agreements. Journal of International Economic Law 20 (2):365-390.

New Zealand MFAT. 1993. New Zealand Trade Policy: Implementation and Directions-a Multi-Track Approach. Wellington: Ministry of Foreign Affairs and Trade.

New Zealand MFAT. 2018. Comprehensive and Progressive Agreement for Trans-Pacific Partnership: National Interest Analysis. Wellington: Ministry of Foreign Affairs and Trade. https://www.mfat.govt.nz/assets/CPTPP/ CPTPP-Final-National-Interest-Analysis-8-March.pdf. 
New Zealand MFAT. 2020. Digital Economy Partnership Agreement: National Interest Analysis. Wellington: Ministry of Foreign Affairs and Trade. https://www.mfat.govt.nz/ assets/Free-trade-agreements/DEPA-Digital-Economy-Partnership-Agreement/ DEPA-NIA-June-2020-for-MFAT-website.pdf.

Newman, Abraham L. 2008. Protectors of Privacy: Regulating Personal Data in the Global Economy. Ithaca, NY: Cornell University Press.

Newman, Abraham L., and Elliot Posner. 2016. Transnational Feedback, Soft Law, and Preferences in Global Financial Regulation. Review of International Political Economy 23 (1):123-152.

North, Douglass C. 1990. Institutions, Institutional Change and Economic Performance. Cambridge: Cambridge University Press.

Odell, John S., and Dustin Tingley. 2016. Negotiating Agreements in International Relations. In Political Negotiation: A Handbook, edited by Jane Mansbridge, and Cathie Jo Martin chapter 7, , 231-285. Online: Brookings Institution Press.

Olson, Mancur. 1965. The Logic of Collective Action: Public Goods and the Theory of Groups. Harvard University Press.

Osgood, Iain, Dustin Tingley, Thomas Bernauer, In Song Kim, Helen V. Milner, and Gabriele Spilker. 2017. The Charmed Life of Superstar Exporters: Survey Evidence on Firms and Trade Policy. Journal of Politics 79 (1):133-152.

Palmer, Glenn, Vito d'Orazio, Michael Kenwick, and Matthew Lane. 2015. The MID4 
Dataset, 2002-2010: Procedures, Coding Rules and Description. Conflict Management and Peace Science 32 (2):222-242.

Peacock, Claire, Karolina Milewicz, and Duncan Snidal. 2019. Boilerplate in International Trade Agreements. International Studies Quarterly 63 (4):923-937.

Pelc, Krzysztof J. 2014. The Politics of Precedent in International Law: A Social Network Application. American Political Science Review 108 (4):886-886.

Pierson, Paul. 2000. Increasing Returns, Path Dependence, and the Study of Politics. The American Political Science Review 94 (2):251-267.

Putnam, Robert D. 1988. Diplomacy and Domestic Politics: The Logic of Two-Level Games. International Organization 42 (3):427-460.

Schelling, Thomas C. 1960. The Strategy of Conflict. Harvard University Press.

Seawright, Jason, and John Gerring. 2008. Case Selection Techniques in Case Study Research: A Menu of Qualitative and Quantitative Options. Political Research Quarterly 61(June):294-308.

Segal, Stephanie. 2018. USMCA Currency Provisions Set a New Precedent. Center for Strategic International Studies Critical Questions October 5.

Steinmo, Sven, and Kathleen Thelen. 1992. Structuring Politics: Historical Institutionalism in Comparative Analysis. Cambridge: Cambridge University Press.

Tallberg, Jonas. 2008. Bargaining Power in the European Council. JCMS: Journal of Common Market Studies 46 (3):685-708. 
Torfing, Jacob. 2009. Rethinking path dependence in public policy research. Critical Policy Studies 3 (1):70-83.

UK DIT. 2019. Public Consultation on Trade Negotiations with New Zealand: Summary of Responses. Vol. July 18 Online: UK Department of International Trade. https://assets. publishing.service.gov.uk/government/uploads/system/uploads/attachment_ data/file/818110/Public_consultation_on_trade_with_New_Zealand.pdf.

UK DIT. 2020a. The Future Relationship with the EU: The UK's Approach to Negotiations. Online: UK Department of International Trade. https: //assets.publishing.service.gov.uk/government/uploads/system/uploads/ attachment_data/file/868874/The_Future_Relationship_with_the_EU.pdf.

UK DIT. 2020b. UK-Australia Free Trade Agreement: The UK's Strategic Approach. Online: Department for International Trade. https://assets.publishing.service. gov.uk/government/uploads/system/uploads/attachment_data/file/901886/ uk-strategy-australia-free-trade-agreement.pdf.

UK DIT. 2020c. UK-Japan Free Trade Agreement: The UK's Strategic Approach. Online: Department for International Trade. https://assets.publishing.service.gov.uk/ government/uploads/system/uploads/attachment_data/file/885176/UK_Japan_ trade_agreement_negotiations_approach.pdf.

UK DIT. 2020d. UK-New Zealand Free Trade Agreement: The UK's Strategic Approach. Online: UK Department of International Trade. https://assets.publishing.service. 
gov.uk/government/uploads/system/uploads/attachment_data/file/901870/

uk-strategy-uk-nz-free-trade-agreement.pdf.

UK DIT. 2020e. UK-US Free Trade Agreement. Online: UK Department of International Trade. https://assets.publishing.service.gov.uk/government/uploads/ system/uploads/attachment_data/file/869592/UK_US_FTA_negotiations.pdf.

UK House of Commons. 2019. Future Free Trade Agreements. Hansard 654(21 February):Column 1619-1690.

Vitalis, Vangelis. 2015. Regional Economic Integration and Multilateralism: The Case of the ASEAN-Australia-New Zealand FTA and the Malaysia-New Zealand FTA. Working Paper 523. Tokyo: Asian Development Bank Institute.

Vitalis, Vangelis. 2018. MFAT testimony to FADT Committee. Wellington: NZ Parliamentary Select Committee, May 3rd.

Young, Jonathan. 2020. International treaty examination of the Digital Economy Partnership Agreement: New Zealand Chile, together with Relationship to other Agreements Side Letter: New Zealand Singapore, Relationship to other Agreements Side Letter: New Zealand Chile. Report of the Economic Development, Science and Innovation Committee https://www.parliament.nz/resource/en-NZ/SCR_99654/ 9521a3186a49ccc666b1dc4f545dbac1874be78b(July). 


\section{Appendix for 'How do Trade Rules Evolve? Strategic Sequencing in International Economic Law'}

This appendix presents summary statistics, additional regression tables, and further details about the data and method used in the paper. Table 1 presents summary statistics for the key variables used in regression models.

Table 1: Summary statistics of key variables

\begin{tabular}{|c|c|c|c|c|c|c|c|}
\hline Variable & Mean & $\mathrm{N}$ & Standard deviation & Minimum & Maximum & Skewness & Kurtosis \\
\hline PTA entry & 0.017 & 1468466 & 0.129 & 0 & 1 & 7.480 & 56.944 \\
\hline PTA depth (Index) & 2.140 & 24440 & 1.854 & 0 & 7 & 1.109 & 3.822 \\
\hline PTA depth (Rasch) & -0.219 & 21204 & 0.981 & -1.728 & 1.885 & 0.072 & 1.882 \\
\hline Times systemic interest cited in a given year & 2.401 & 173524 & 1.980 & 0 & 10 & .670 & 2.858 \\
\hline Total times systemic interest cited* & 26.37811 & 957307 & 31.66315 & 0 & 75 & .7501622 & 1.741292 \\
\hline Sum of GDP (lagged 5 years) & 46.494 & 894160 & 3.495 & 33.043 & 60.902 & 0.165 & 2.900 \\
\hline Difference in GDP (lagged 5 years) & 2.759 & 894160 & 2.051 & 0 & 13.676 & 0.895 & 3.446 \\
\hline Logged exports (lagged 10 years) & 7.398 & 1071143 & 7.795 & 0 & 27.159 & 0.275 & 1.380 \\
\hline Previous FTAs (own, t-5) & 8.074 & 1300995 & 12.645 & -1 & 88 & 3.206 & 15.472 \\
\hline Previous FTAs (partner's, t-5) & 7.677 & 1300995 & 12.254 & -1 & 88 & 3.307 & 16.437 \\
\hline Previous PTAs (ROW, t-5) & 337.290 & 1468466 & 276.485 & 0 & 789 & 0.339 & 1.546 \\
\hline Polity scores (own) & 2.048 & 1189033 & 7.265 & -10 & 10 & -0.307 & 1.433 \\
\hline Polity scores (partner) & 1.643 & 1138271 & 7.314 & -10 & 10 & -0.229 & 1.387 \\
\hline Distance (logged) & 8.729 & 1379754 & 0.784 & 4.088 & 9.899 & -1.284 & 5.159 \\
\hline Remoteness & 1.683 & 1389354 & 3.371 & 0 & 9.422 & 1.506 & 3.275 \\
\hline Same continent & 0.243 & 1468466 & 0.429 & 0 & 1 & 1.200 & 2.440 \\
\hline Year & 1988.303 & 1470865 & 18.282 & 1947 & 2018 & -0.388 & 2.009 \\
\hline PTA flexibility (additive measure) & 0.986 & 24618 & 1.763 & 0 & 7 & 1.829 & 5.130 \\
\hline PTA flexibility (long-term) & 2.284 & 24618 & 1.351 & 0 & 4 & -0.024 & 1.817 \\
\hline Bureaucratic recruitment criteria (own) & 0.483 & 1220934 & 1.238 & -3.194 & 3.6 & 0.106 & 2.266 \\
\hline Bureaucratic remuneration (own) & 0.490 & 1208136 & 0.947 & -4.044 & 1.713 & -0.786 & 3.070 \\
\hline GWP change & 3.833 & 1456415 & 1.318 & -0.100 & 6.269 & -0.572 & 3.436 \\
\hline Hegemony & 13.853 & 1468406 & 2.074 & 10.124 & 19.578 & 0.375 & 3.147 \\
\hline Alliance & 0.082 & 1468466 & 0.275 & 0 & 1 & 3.038 & 10.230 \\
\hline Colonial relationship post- 1945 & 0.009 & 1379754 & 0.097 & 0 & 1 & 10.124 & 103.503 \\
\hline Previous conflict & 0.005 & 1468466 & 0.072 & 0 & 1 & 13.794 & 191.275 \\
\hline
\end{tabular}

* The figure for total cites of systemic interest is adjusted so that all EU members have the same score of 75 , as the EU speaks with one voice at the WTO and has exclusive competence over trade policy.

Table 2 lists those states identified as having high levels of interest in the systemic implications of global trade rules. The measure is based on states' announced justification for participating as interested third parties in World Trade Organization (WTO) disputes. WTO members can participate as interested third parties in disputes on the basis of a direct trade interest in the outcome of the dispute, and on the basis of a systemic interest in the interpretation of the rules relating to the proceedings (or both). This justification is typically communicated in the member's statement to the chair of the panel that has been composed to adjudicate the dispute between members, or in a formal request to join consultations; such third party submissions are included in the panel reports and Appellate Body reports available through the WTO's Dispute Settlement web portal 1

As an illustration, I count Canada's oral third party statement in the Brazil-United States cotton dispute (DS267: United States-Subsidies on Upland Cotton), as indicative of a systemic interest in the rules at hand, given the explicit reference to systemic interest: "Canada's statement today conveys our systemic interest in the interpretation of certain provisions of the Agriculture Agreement and the SCM Agreement regarding certain aspects of Brazil's claims.' 2 2 In contrast, I do not count Benin's oral third party statement as indicative of a systemic interest in the rules at hand,

${ }^{1}$ https://www.wto.org/english/tratop_e/dispu_e/dispu_status_e.htm

${ }^{2}$ Panel Report, United States-Subsidies on Upland Cotton (Addendum), WTO doc WT/DS267/R/Add.1; p.C-36. 
as it makes no reference to systemic concerns, instead stressing the country's commercial interest in the case by detailing the importance of the cotton sector for Benin's economy and society:

"The importance of the cotton sector to Benin can hardly be overstated. As noted in our submission, it accounts for 90 per cent of our agricultural exports, and threequarters of our export earnings over the past four years. It generates 25 per cent of national revenues. In total, about a million people in Benin - out of a total population of six million - depend on cotton or cotton-related activities. Cotton plays a particularly important role in rural areas, where national poverty reaches its highest levels." 3

The most recent dispute appearing in the data is DS492, for which a panel report was adopted on 19 April 2017, and a mutually agreed solution between the disputants was notified on 30 May 2019. The mean number of times a third party cites a systemic interest in the rules at issue in a WTO dispute is 9.2 ; the countries listed in Table 2 are coded as having a STROng Systemic interest, with a total of 10 or more cites of systemic interest.

Table 3 lists 'excessive' PTAs signed by countries with a STRONG SYSTEMIC interest, while Table 4 lists 'excessive' PTAs signed by countries with a WEAK SYSTEMIC interest. There is a small degree of overlap in the two lists of PTAs due to the fact that an agreement may be signed between countries that score higher and lower on the systemic interest measure. This is not a concern for the key findings of the paper. If anything it should bias the effects of an 'excessive' PTA downwards for STRONG SYSTEMIC states, and the theory does not lead to a clear expectation for the behavior of WEAK SYSTEMIC states besides being less strategic than their STRONG SYSTEMIC counterparts.

Table 2: States with strong concern for systemic implications of WTO rules

\begin{tabular}{lll}
\hline \hline Argentina & Hungary & New Zealand \\
Australia & Finland & Norway \\
Austria & France & Poland \\
Belgium & Germany & Portugal \\
Belgium-Luxembourg & Greece & Romania \\
Brazil & Hungary & Saudi Arabia \\
Bulgaria & India & Slovak Republic \\
Canada & Ireland & Slovenia \\
Chile & Italy & Spain \\
China & Japan & Sweden \\
Taiwan & Republic of Korea & Thailand \\
Colombia & Latvia & Turkey \\
Croatia & Lithuania & United Kingdom \\
Cyprus & Malta & United States \\
Czech Republic & Mexico & \\
Denmark & Netherlands \\
\hline \hline
\end{tabular}

\footnotetext{
${ }^{3}$ Panel Report, United States-Subsidies on Upland Cotton (Addendum), WTO doc WT/DS267/R/Add.1; p.C-33.
} 
Table 3: Excessive bilateralism (strong systemic concerns)

\begin{tabular}{|c|c|}
\hline Algeria EC & EC Morocco Association Agreement \\
\hline Algeria EC Euro-Med Association Agreement & EC Nice \\
\hline Argentina Mexico & EC Portugal \\
\hline Association of Southeast Asian Nations (ASEAN) FTA & EC Single European Act \\
\hline Association of Southeast Asian Nations Australia New Zealand FTA (AANZFTA) & EC South Africa \\
\hline Association of Southeast Asian Nations China & EC Syria \\
\hline Association of Southeast Asian Nations China Services & EC Tunisia \\
\hline Association of Southeast Asian Nations India & EC Tunisia Euro-Med Association Agreement \\
\hline Association of Southeast Asian Nations Japan & EFTA Egypt \\
\hline Association of Southeast Asian Nations Korea & EFTA GCC \\
\hline Association of Southeast Asian Nations Korea services & EFTA Israel \\
\hline Australia Chile & EFTA Jordan \\
\hline Australia China & EFTA Mexico \\
\hline Australia Japan & EFTA Morocco \\
\hline Australia Korea & EFTA Singapore \\
\hline Australia Malaysia & EFTA Southern African Customs Union (SACU) \\
\hline Australia Papua New Guinea & EFTA Tunisia \\
\hline Australia US & Egypt MERCOSUR \\
\hline Bahrain US & Egypt Saudi Arabia \\
\hline Bangkok Agreement & El Salvador Mexico \\
\hline Brazil Cuba & European Economic Area (EEA) \\
\hline Brazil Guyana & Georgia Turkey \\
\hline Bulgaria Israel & Greater Arab Free Trade Agreement \\
\hline CARIFORUM EC EPA & Gulf Cooperation Council (GCC) \\
\hline Canada Costa Rica & Gulf Cooperation Council (GCC) Singapore \\
\hline Canada EC (CETA) & Hungary Israel \\
\hline Canada EFTA & India MERCOSUR \\
\hline Canada Jordan & Indonesia Japan \\
\hline Canada Korea & Inter-Arab Trade Agreement \\
\hline Canada New Zealand & Israel MERCOSUR \\
\hline Central America EC & Israel Mexico \\
\hline Chile EC & Israel Poland \\
\hline Chile India & Japan Mongolia \\
\hline Chile Japan & Japan Switzerland \\
\hline Chile Turkey & Japan Thailand \\
\hline China New Zealand & Jordan Turkey \\
\hline China Peru & Jordan US \\
\hline China Singapore & Korea Turkey \\
\hline Colombia EFTA & Korea US \\
\hline Colombia Peru EC & Korea US environmental side agreement \\
\hline Cote d'Ivoire EC EPA & Latin American Integration Association (ALADI LAIA) \\
\hline D8 PTA & MERCOSUR Southern African Customs Union (SACU) \\
\hline EC Egypt & Malaysia New Zealand \\
\hline EC Egypt Agreement & Malaysia Turkey \\
\hline EC Egypt Euro-Med Association Agreement & Mexico Uruguay \\
\hline EC Finland & Morocco Turkey \\
\hline EC Georgia & Morocco US \\
\hline EC Israel & New Zealand Singapore \\
\hline EC Jordan & North American Free Trade Agreement (NAFTA) \\
\hline EC Jordan Euro-Med Association Agreement & Oman US \\
\hline EC Korea & Panama US \\
\hline EC Lisbon & Saudi Arabia Syria \\
\hline EC Mexico & South Asian Free Trade Area (SAFTA) \\
\hline EC Moldova & Transpacific Partnership (TPP) \\
\hline EC Morocco & Tunisia Turkey \\
\hline
\end{tabular}


Table 4: Excessive bilateralism (weak systemic concerns)

\begin{tabular}{|c|c|}
\hline African Economic Community & EFTA GCC \\
\hline Agadir Agreement & EFTA Jordan \\
\hline Albania EC SAA & EFTA Korea \\
\hline Algeria EC & EFTA Mexico \\
\hline Algeria Jordan & EFTA Morocco \\
\hline Andean Community Sucre Protocol & EFTA Peru \\
\hline Armenia Estonia & EFTA Singapore \\
\hline Association of Caribbean States & EFTA Southern African Customs Union (SACU) \\
\hline Association of Southeast Asian Nations Australia New Zealand FTA (AANZFTA) & EFTA Tunisia \\
\hline Association of Southeast Asian Nations China & Economic Community Of West African States (ECOWAS) \\
\hline Association of Southeast Asian Nations Japan & Economic Cooperation Organization (ECO) Preferences \\
\hline Association of Southeast Asian Nations Korea & Economic Cooperation Organization Trade Agreement (ECOTA) \\
\hline Association of Southeast Asian Nations Korea services & Egypt MERCOSUR \\
\hline Australia Malaysia & Egypt Syria \\
\hline Australia Papua New Guinea & Greater Arab Free Trade Agreement \\
\hline Australia Papua New Guinea & Guinea Morocco \\
\hline Australia Singapore & Gulf Cooperation Council (GCC) \\
\hline Azerbaijan Belarus & Gulf Cooperation Council (GCC) Singapore \\
\hline Bahrain US & Guyana Panama \\
\hline Bangkok Agreement & Hungary Israel \\
\hline Bulgaria Israel & India MERCOSUR \\
\hline CARIFORUM EC EPA & Indonesia Pakistan \\
\hline Canada EC (CETA) & Inter-Arab Trade Agreement \\
\hline Canada EFTA & Iran Pakistan \\
\hline Canada Israel & Iran Sri Lanka \\
\hline Canada Jordan & Israel MERCOSUR \\
\hline Caribbean Community (CARICOM) & Israel Mexico \\
\hline Caribbean Community (CARICOM) Costa Rica & Israel Panama \\
\hline Caribbean Community (CARICOM) Protocol on Services & Israel Poland \\
\hline Central America EC & Israel US \\
\hline Central America EFTA & Japan Peru \\
\hline Central American Free Trade Agreement (CAFTA) & Japan Philippines \\
\hline Central American Free Trade Agreement (CAFTA) Dominican Republic & Japan Switzerland \\
\hline Central European Free Trade Agreement (CEFTA) & Jordan Morocco \\
\hline Chad Morocco & Jordan Singapore \\
\hline Chile EFTA & Jordan Sudan \\
\hline Chile Malaysia & Jordan US \\
\hline China Costa Rica & Korea Peru \\
\hline China Peru & MERCOSUR Southern African Customs Union (SACU) \\
\hline Colombia EFTA & Malaysia New Zealand \\
\hline Colombia Israel & Malaysia Turkey \\
\hline Colombia Peru EC & Mauritius Pakistan \\
\hline Common Economic Zone & Mauritius Turkey \\
\hline Common Market for Eastern and Southern Africa (COMESA) & Melanesian Spearhead Group (MSG) \\
\hline Commonwealth of Independent States (CIS) & Morocco Turkey \\
\hline Costa Rica Dominican Republic & Morocco UAE \\
\hline Costa Rica Singapore & Morocco US \\
\hline Cote d'Ivoire EC EPA & New Zealand Singapore \\
\hline Croatia Moldova & Oman US \\
\hline D8 PTA & PTA for Eastern and Southern African States \\
\hline EC Egypt & Panama Singapore \\
\hline EC Egypt Agreement & Panama US environmental side agreement \\
\hline EC Egypt Euro-Med Association Agreement & Peru Singapore \\
\hline EC Georgia & Peru Thailand \\
\hline EC Israel & Singapore US \\
\hline EC Jordan & South Asian Association for Regional Cooperation, Preferential Trading Arrangement (SAPTA) \\
\hline EC Jordan Euro-Med Association Agreement & South Asian Free Trade Area (SAFTA) \\
\hline EC Morocco & Syria Turkey \\
\hline EC Morocco Association Agreement & Trans Pacific Strategic EPA \\
\hline EC Syria & Transpacific Partnership (TPP) \\
\hline EC Tunisia & Tunisia Turkey \\
\hline EFTA Egypt & Uruguay Venezuela \\
\hline
\end{tabular}




\section{Additional regression tables}

Table 5 presents results for the first-stage models predicting PTA entry, using additional control variables. I add a row at the top of each column that presents the bivariate correlation between excessive bilateralism and agreement depth for each set of estimations. This illustrates simply that excessive bilateralism and agreement depth are positively correlated. Beneath this are the results from t-tests, which show that there is a statistically significant difference between the depth of excessive PTAs and the depth of other PTAs. The binary outcome variable PTA is coded 1 when countries A and B enter a PTA and 0 otherwise. Columns 1-3 present the results without ten-year lagged exports, while Columns 4-6 present the results with lagged exports. As indicated in the table, the sample is split into three groups: all countries (Columns 1 and 4), countries that have demonstrated a strong interest in the systemic impact of trade norms (Columns 2 and 5), and other countries (Columns 3 and 6).

Table 5: Predicting entry into a Preferential Trade Agreement

\begin{tabular}{|c|c|c|c|c|c|c|c|c|c|}
\hline \multirow[t]{2}{*}{ Model } & $\begin{array}{c}(1) \\
\text { All states }\end{array}$ & $\begin{array}{c}(2) \\
\text { High systemic }\end{array}$ & $\begin{array}{c}(3) \\
\text { Low systemic }\end{array}$ & $\begin{array}{c}(4) \\
\text { All states }\end{array}$ & $\begin{array}{c}\text { DV: PTA entr } \\
(5) \\
\text { High systemic }\end{array}$ & $\begin{array}{l}\text { y } \\
\text { Low systemic }\end{array}$ & $\begin{array}{c}(7) \\
\text { All states }\end{array}$ & $\begin{array}{c}(8) \\
\text { High systemic }\end{array}$ & $\begin{array}{c}(9) \\
\text { Low systemic }\end{array}$ \\
\hline & \multicolumn{3}{|c|}{ Trade } & & & & \multicolumn{3}{|c|}{ Bureaucratic capacity } \\
\hline Biv. Corr.: Excess \& depth & 0.11 & 0.16 & 0.14 & 0.12 & 0.12 & 0.16 & 0.09 & 0.12 & 0.14 \\
\hline $\begin{array}{l}\text { Difference in means (t-test) } \\
{[95 \% \text { conf. int. }]}\end{array}$ & {$[-.33,-.20]$} & {$[-.36,-.22]$} & {$[-.40,-.24]$} & {$[-.36,-.23]$} & {$[-.28,-.14]$} & {$[-.43,-.28]$} & {$[-.29,-.15]$} & {$[-.28,-.14]$} & {$[-.41,-.25]$} \\
\hline Distance (logged) & $\begin{array}{c}-0.40^{* * *} \\
(0.03)\end{array}$ & $\begin{array}{c}-0.28^{* * *} \\
(0.04)\end{array}$ & $\begin{array}{c}-0.56^{* * *} \\
(0.03)\end{array}$ & $\begin{array}{c}-0.54^{* * * *} \\
(0.02)\end{array}$ & $\begin{array}{c}-0.28^{* * *} \\
(0.04)\end{array}$ & $\begin{array}{c}-0.67^{* * * *} \\
(0.03)\end{array}$ & $\begin{array}{c}-0.52^{* * * *} \\
(0.03)\end{array}$ & $\begin{array}{c}-0.27^{* * *} \\
(0.04)\end{array}$ & $\begin{array}{c}-0.65^{* * *} \\
(0.03)\end{array}$ \\
\hline Remoteness & $\begin{array}{c}1.44^{* * *} \\
(0.18)\end{array}$ & $\begin{array}{c}0.37 \\
(0.38)\end{array}$ & $\begin{array}{c}2.23^{* * * *} \\
(0.22)\end{array}$ & $\begin{array}{c}0.68^{* * *} \\
(0.12)\end{array}$ & $\begin{array}{c}0.55^{* * *} \\
(0.18)\end{array}$ & $\begin{array}{c}1.08^{* * *} \\
(0.17)\end{array}$ & $\begin{array}{c}0.91^{* * *} \\
(0.12)\end{array}$ & $\begin{array}{c}0.87^{* * *} \\
(0.16)\end{array}$ & $\begin{array}{c}1.26^{* * *} \\
(0.17)\end{array}$ \\
\hline Same continent & $\begin{array}{c}-10.67^{* * *} \\
(1.51)\end{array}$ & $\begin{array}{l}-1.95 \\
(3.16)\end{array}$ & $\begin{array}{c}-16.95^{* * * *} \\
(1.90)\end{array}$ & $\begin{array}{c}-4.34^{* * * *} \\
(1.02)\end{array}$ & $\begin{array}{c}-3.30^{* *} \\
(1.47)\end{array}$ & $\begin{array}{c}-7.65^{* * *} \\
(1.40)\end{array}$ & $\begin{array}{c}-6.28^{* * * *} \\
(1.02)\end{array}$ & $\begin{array}{c}-6.07^{* * *} \\
(1.35)\end{array}$ & $\begin{array}{c}-9.19^{* * *} \\
(1.43)\end{array}$ \\
\hline GDP sum (logged, t-5) & $\begin{array}{l}-0.01 \\
(0.01)\end{array}$ & $\begin{array}{l}-0.02 \\
(0.02)\end{array}$ & $\begin{array}{l}0.02^{*} \\
(0.01)\end{array}$ & $\begin{array}{c}0.03^{* * *} \\
(0.01)\end{array}$ & $\begin{array}{c}0.04^{* * *} \\
(0.01)\end{array}$ & $\begin{array}{l}0.02^{* *} \\
(0.01)\end{array}$ & $\begin{array}{c}0.01 \\
(0.01)\end{array}$ & $\begin{array}{c}0.06^{* * *} \\
(0.01)\end{array}$ & $\begin{array}{l}-0.00 \\
(0.01)\end{array}$ \\
\hline GDP difference (logged, t-5) & $\begin{array}{c}-0.14^{* * *} \\
(0.01)\end{array}$ & $\begin{array}{c}-0.14^{* * *} \\
(0.02)\end{array}$ & $\begin{array}{c}-0.13^{* * * *} \\
(0.01)\end{array}$ & $\begin{array}{c}-0.13^{* * *} \\
(0.01)\end{array}$ & $\begin{array}{c}-0.15^{* * *} \\
(0.01)\end{array}$ & $\begin{array}{c}-0.12^{* * * *} \\
(0.01)\end{array}$ & $\begin{array}{c}-0.10^{* * *} \\
(0.01)\end{array}$ & $\begin{array}{c}-0.12^{* * *} \\
(0.01)\end{array}$ & $\begin{array}{c}-0.10^{* * *} \\
(0.02)\end{array}$ \\
\hline Previous PTAs (own, t-5) & $\begin{array}{c}0.01^{* * *} \\
(0.00)\end{array}$ & $\begin{array}{c}0.01^{* * *} \\
(0.00)\end{array}$ & $\begin{array}{c}0.02^{* * *} \\
(0.00)\end{array}$ & $\begin{array}{c}0.01^{* * *} \\
(0.00)\end{array}$ & $\begin{array}{c}0.01^{* * *} \\
(0.00)\end{array}$ & $\begin{array}{c}0.02^{* * *} \\
(0.00)\end{array}$ & $\begin{array}{c}0.01^{* * *} \\
(0.00)\end{array}$ & $\begin{array}{c}0.00^{* * *} \\
(0.00)\end{array}$ & $\begin{array}{c}0.02^{* * *} \\
(0.00)\end{array}$ \\
\hline Previous PTAs (partner, t-5) & $\begin{array}{c}0.01^{* * *} \\
(0.00)\end{array}$ & $\begin{array}{c}0.01^{* * *} \\
(0.00)\end{array}$ & $\begin{array}{c}0.02^{* * *} \\
(0.00)\end{array}$ & $\begin{array}{c}0.01^{* * *} \\
(0.00)\end{array}$ & $\begin{array}{c}0.00^{* * *} \\
(0.00)\end{array}$ & $\begin{array}{c}0.03^{* * *} \\
(0.00)\end{array}$ & $\begin{array}{c}0.01^{* * *} \\
(0.00)\end{array}$ & $\begin{array}{c}0.00^{* * * *} \\
(0.00)\end{array}$ & $\begin{array}{c}0.02^{* * *} \\
(0.00)\end{array}$ \\
\hline Previous PTAs (ROW, t-5) & $\begin{array}{l}0.00^{* *} \\
(0.00)\end{array}$ & $\begin{array}{c}0.03^{* * *} \\
(0.00)\end{array}$ & $\begin{array}{c}0.00 \\
(0.00)\end{array}$ & $\begin{array}{l}0.00^{*} \\
(0.00)\end{array}$ & $\begin{array}{c}0.01^{* * *} \\
(0.00)\end{array}$ & $\begin{array}{c}0.00 \\
(0.00)\end{array}$ & $\begin{array}{c}0.00^{* * *} \\
(0.00)\end{array}$ & $\begin{array}{c}0.01^{* * * *} \\
(0.00)\end{array}$ & $\begin{array}{l}0.00^{* *} \\
(0.00)\end{array}$ \\
\hline Previous PTAs (ROW, t-5, squared) & $\begin{array}{c}-0.00^{* * * *} \\
(0.00)\end{array}$ & $\begin{array}{c}-0.00^{* * *} \\
(0.00)\end{array}$ & $\begin{array}{c}-0.00^{* * *} \\
(0.00)\end{array}$ & $\begin{array}{c}-0.00^{* * * *} \\
(0.00)\end{array}$ & $\begin{array}{c}-0.00^{* * *} \\
(0.00)\end{array}$ & $\begin{array}{c}-0.00^{* * * *} \\
(0.00)\end{array}$ & $\begin{array}{c}-0.00^{* * *} \\
(0.00)\end{array}$ & $\begin{array}{c}-0.00^{* * * *} \\
(0.00)\end{array}$ & $\begin{array}{c}-0.00^{* * * *} \\
(0.00)\end{array}$ \\
\hline Alliance & $\begin{array}{c}0.28^{* * *} \\
(0.06)\end{array}$ & $\begin{array}{c}0.12 \\
(0.08)\end{array}$ & $\begin{array}{c}0.51^{* * *} \\
(0.08)\end{array}$ & $\begin{array}{c}0.30^{* * *} \\
(0.05)\end{array}$ & $\begin{array}{c}0.19^{* * *} \\
(0.07)\end{array}$ & $\begin{array}{c}0.37^{* * *} \\
(0.07)\end{array}$ & $\begin{array}{c}0.38^{* * *} \\
(0.05)\end{array}$ & $\begin{array}{c}0.20^{* * * *} \\
(0.07)\end{array}$ & $\begin{array}{c}0.45^{* * *} \\
(0.07)\end{array}$ \\
\hline Previous conflict & $\begin{array}{l}-0.14 \\
(0.17)\end{array}$ & $\begin{array}{c}0.14 \\
(0.36)\end{array}$ & $\begin{array}{l}-0.32^{*} \\
(0.17)\end{array}$ & $\begin{array}{l}-0.32^{*} \\
(0.18)\end{array}$ & $\begin{array}{l}-0.01 \\
(0.36)\end{array}$ & $\begin{array}{c}-0.48^{* *} \\
(0.19)\end{array}$ & $\begin{array}{c}-0.35^{*} \\
(0.18)\end{array}$ & $\begin{array}{c}-0.16 \\
(0.35)\end{array}$ & $\begin{array}{c}-0.50^{* *} \\
(0.20)\end{array}$ \\
\hline GWP change & $\begin{array}{c}-0.07^{* * * *} \\
(0.01)\end{array}$ & $\begin{array}{c}0.12^{* * *} \\
(0.02)\end{array}$ & $\begin{array}{c}-0.24^{* * * *} \\
(0.02)\end{array}$ & $\begin{array}{c}-0.08^{* * *} \\
(0.01)\end{array}$ & $\begin{array}{c}0.11^{* * *} \\
(0.02)\end{array}$ & $\begin{array}{c}-0.24^{* * * *} \\
(0.02)\end{array}$ & $\begin{array}{c}-0.08^{* * * *} \\
(0.01)\end{array}$ & $\begin{array}{c}0.10^{* * *} \\
(0.02)\end{array}$ & $\begin{array}{c}-0.23^{* * *} \\
(0.02)\end{array}$ \\
\hline Hegemony & $\begin{array}{c}-0.51^{* * * *} \\
(0.02)\end{array}$ & $\begin{array}{c}-0.46^{* * * *} \\
(0.04)\end{array}$ & $\begin{array}{c}-0.55^{* * * *} \\
(0.03)\end{array}$ & $\begin{array}{c}-0.40^{* * * *} \\
(0.02)\end{array}$ & $\begin{array}{c}-0.30^{* * * *} \\
(0.03)\end{array}$ & $\begin{array}{c}-0.42^{* * * *} \\
(0.03)\end{array}$ & $\begin{array}{c}-0.38^{* * * *} \\
(0.02)\end{array}$ & $\begin{array}{c}-0.28^{* * *} \\
(0.03)\end{array}$ & $\begin{array}{c}-0.41^{* * * *} \\
(0.03)\end{array}$ \\
\hline Polity scores (own) & $\begin{array}{c}-0.01^{* * * *} \\
(0.00)\end{array}$ & $\begin{array}{c}0.00 \\
(0.01)\end{array}$ & $\begin{array}{l}-0.00 \\
(0.00)\end{array}$ & $\begin{array}{l}0.00^{* *} \\
(0.00)\end{array}$ & $\begin{array}{c}0.02^{* * *} \\
(0.01)\end{array}$ & $\begin{array}{l}-0.00 \\
(0.00)\end{array}$ & $\begin{array}{c}0.00 \\
(0.00)\end{array}$ & $\begin{array}{c}0.03^{* * * *} \\
(0.01)\end{array}$ & $\begin{array}{l}-0.00 \\
(0.00)\end{array}$ \\
\hline Polity scores (partner) & $\begin{array}{c}-0.01^{* *} \\
(0.00)\end{array}$ & $\begin{array}{c}0.04^{* * *} \\
(0.01)\end{array}$ & $\begin{array}{c}-0.02^{* * *} \\
(0.00)\end{array}$ & $\begin{array}{l}0.00^{* *} \\
(0.00)\end{array}$ & $\begin{array}{c}0.06^{* * *} \\
(0.01)\end{array}$ & $\begin{array}{c}-0.01^{* * *} \\
(0.00)\end{array}$ & $\begin{array}{c}0.00 \\
(0.00)\end{array}$ & $\begin{array}{c}0.06^{* * *} \\
(0.01)\end{array}$ & $\begin{array}{c}-0.02^{* * *} \\
(0.00)\end{array}$ \\
\hline Both in GATT & $\begin{array}{l}-0.06 \\
(0.05)\end{array}$ & $\begin{array}{l}0.13^{* *} \\
(0.06)\end{array}$ & $\begin{array}{l}-0.10^{*} \\
(0.06)\end{array}$ & $\begin{array}{l}-0.00 \\
(0.04)\end{array}$ & $\begin{array}{l}-0.04 \\
(0.06)\end{array}$ & $\begin{array}{c}0.04 \\
(0.05)\end{array}$ & $\begin{array}{l}-0.07 \\
(0.05)\end{array}$ & $\begin{array}{c}-0.14^{* * * *} \\
(0.05)\end{array}$ & $\begin{array}{l}-0.03 \\
(0.06)\end{array}$ \\
\hline Both in WTO & $\begin{array}{c}0.36^{* * *} \\
(0.06)\end{array}$ & $\begin{array}{l}0.19^{* *} \\
(0.09)\end{array}$ & $\begin{array}{l}0.19^{* *} \\
(0.08)\end{array}$ & $\begin{array}{c}0.39^{* * *} \\
(0.06)\end{array}$ & $\begin{array}{c}0.53^{* * *} \\
(0.09)\end{array}$ & $\begin{array}{l}0.14^{*} \\
(0.07)\end{array}$ & $\begin{array}{c}0.37^{* * * *} \\
(0.06)\end{array}$ & $\begin{array}{c}0.57^{* * * *} \\
(0.09)\end{array}$ & $\begin{array}{l}0.14^{*} \\
(0.08)\end{array}$ \\
\hline Post-Cold War & $\begin{array}{c}0.81^{* * * *} \\
(0.12)\end{array}$ & $\begin{array}{c}-0.36^{*} \\
(0.20)\end{array}$ & $\begin{array}{c}1.06^{* * *} \\
(0.13)\end{array}$ & $\begin{array}{c}1.44^{* * *} \\
(0.08)\end{array}$ & $\begin{array}{c}0.13 \\
(0.10)\end{array}$ & $\begin{array}{c}1.88^{* * *} \\
(0.09)\end{array}$ & $\begin{array}{c}1.40^{* * *} \\
(0.08)\end{array}$ & $\begin{array}{c}0.01 \\
(0.11)\end{array}$ & $\begin{array}{c}1.87^{* * *} \\
(0.10)\end{array}$ \\
\hline Colonial relationship post- 1945 & $\begin{array}{c}-0.27 \\
(0.24)\end{array}$ & $\begin{array}{c}-0.21 \\
(0.30)\end{array}$ & $\begin{array}{l}-0.23 \\
(0.23)\end{array}$ & $\begin{array}{l}-0.13 \\
(0.26)\end{array}$ & $\begin{array}{l}-0.26 \\
(0.33)\end{array}$ & $\begin{array}{c}-0.01 \\
(0.23)\end{array}$ & $\begin{array}{c}-0.49^{*} \\
(0.25)\end{array}$ & $\begin{array}{c}-0.55^{*} \\
(0.29)\end{array}$ & $\begin{array}{c}-0.49^{*} \\
(0.27)\end{array}$ \\
\hline Exports (logged, t-10) & $\begin{array}{c}0.03^{* * *} \\
(0.00)\end{array}$ & $\begin{array}{c}0.04^{* * *} \\
(0.01)\end{array}$ & $\begin{array}{c}0.02^{* * *} \\
(0.00)\end{array}$ & & & & & & \\
\hline Bureaucratic remuneration (own) & & & & & & & $\begin{array}{l}-0.01 \\
(0.02)\end{array}$ & $\begin{array}{l}-0.06^{*} \\
(0.04)\end{array}$ & $\begin{array}{l}-0.02 \\
(0.02)\end{array}$ \\
\hline Bureaucratic recruitment criteria (own) & & & & & & & $\begin{array}{c}0.13^{* * *} \\
(0.02)\end{array}$ & $\begin{array}{c}0.13^{* * *} \\
(0.03)\end{array}$ & $\begin{array}{c}0.09^{* * *} \\
(0.02)\end{array}$ \\
\hline Bureaucratic remuneration (partner) & & & & & & & $\begin{array}{l}-0.00 \\
(0.02)\end{array}$ & $\begin{array}{c}0.10^{* * * *} \\
(0.03)\end{array}$ & $\begin{array}{c}-0.04^{*} \\
(0.02)\end{array}$ \\
\hline Bureaucratic recruitment criteria (partner) & & & & & & & $\begin{array}{c}0.13^{* * *} \\
(0.02)\end{array}$ & $\begin{array}{c}0.02 \\
(0.03)\end{array}$ & $\begin{array}{c}0.20^{* * *} \\
(0.02)\end{array}$ \\
\hline Constant & $\begin{array}{c}383.16^{* * *} \\
(37.45)\end{array}$ & $\begin{array}{c}340.06^{* * *} \\
(65.98)\end{array}$ & $\begin{array}{c}539.71^{* * * *} \\
(41.97)\end{array}$ & $\begin{array}{c}3.45^{* * *} \\
(0.49)\end{array}$ & $\begin{array}{c}-1.68^{* *} \\
(0.77)\end{array}$ & $\begin{array}{c}5.14^{* * *} \\
(0.60)\end{array}$ & $\begin{array}{c}3.28^{* * * *} \\
(0.55)\end{array}$ & $\begin{array}{c}-3.23^{* * *} \\
(0.80)\end{array}$ & $\begin{array}{c}5.59^{* * * *} \\
(0.66)\end{array}$ \\
\hline Continent dummies & Yes & Yes & Yes & No & No & No & No & No & No \\
\hline Cubic spline function & Yes & Yes & Yes & No & No & No & No & No & No \\
\hline $\mathrm{N}$ & 561870 & 194290 & 367580 & 628723 & 205629 & 423094 & 550286 & 174529 & 375757 \\
\hline Pseudo R-squared & 0.19 & 0.18 & 0.24 & 0.19 & 0.17 & 0.23 & 0.18 & 0.17 & 0.22 \\
\hline
\end{tabular}


Figure 1: Probability density plot of depth: Excessive and other PTAs (Model 4)

(a) Predicted bilateralism

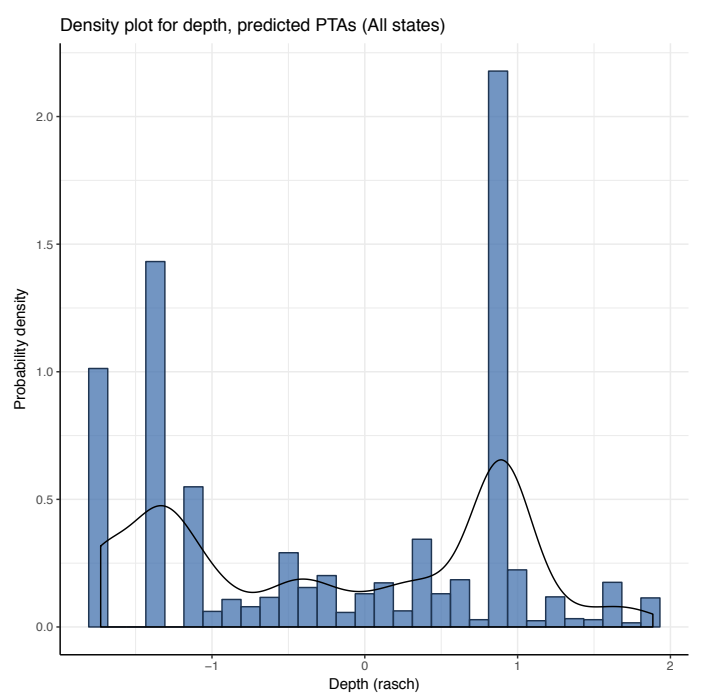

(b) Excessive bilateralism

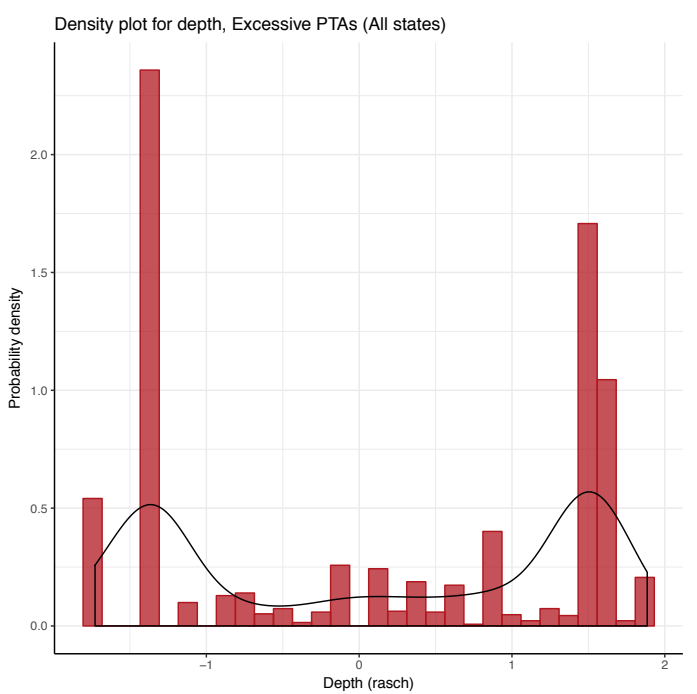

Based on the model in Column 4 (all countries), Table6 6 illustrates the creation of the ExCESSIVE Bilateralism variable. Here, there are 2,359 dyad-year observations where a PTA that was not economically or politically predicted was signed. I give these observations of PTA entry a value of '1' on the Excessive Bilateralism variable, and '0' otherwise.

Table 6: PTAs: actual and predicted (all states, Model 4)

\begin{tabular}{lrrr}
\hline \hline & \multicolumn{3}{c}{ Predicted PTA signature } \\
PTA signed & Not predicted & Predicted & Total \\
\hline No PTA & 381,919 & 239,906 & 621,825 \\
PTA signed & $\mathbf{2 , 3 5 9}$ & 4,539 & 6,898 \\
Total & 384,278 & 244,445 & 628,723 \\
\hline Pearson Chi-sq(1) $=2.1 \mathrm{e}+03$ & & $\mathbf{P r}=0.000$ & \\
\hline \hline
\end{tabular}

Table 5 also presents bivariate correlations between Excessive Bilateralism and AgEement DEPTH, as well as t-tests for the difference in means between Excessive and Predicted agreements. The relationship between excessive bilateralism agreement depth indicates that agreements that are under-predicted by an economic and political gravity model are positively correlated with depth. T-tests confirm that the mean depth of excessive PTAs and other PTAs differs significantly.

Figure 1 shows this graphically. The depth of excessive agreements clusters at the upper and lower extremes. While a relatively large number of predicted PTAs are low in depth, a disproportionately number of high-depth agreements are excessive. States have signed ambitious agreements with partners that are not well-predicted by an economic and political gravity model. 


\section{Alternative model specifications}

In this section I present alternative model specifications as robustness checks on the results. In Table 7 I present models that introduce additional control variables: bureaucratic remuneration and recruitment criteria; the highest previous PTA depth; and PTA flexibility. In the main text I introduce these together in the interest of space. Here I do so separately to show that the separate effects of these variables are as expected. Columns 1-3 present regressions for countries with high systemic concerns; columns 4-6 present regressions for countries with low systemic concerns; columns 7-9 present regressions for all states.

Table 7: Excessive bilateralism and agreement depth: alternative specifications

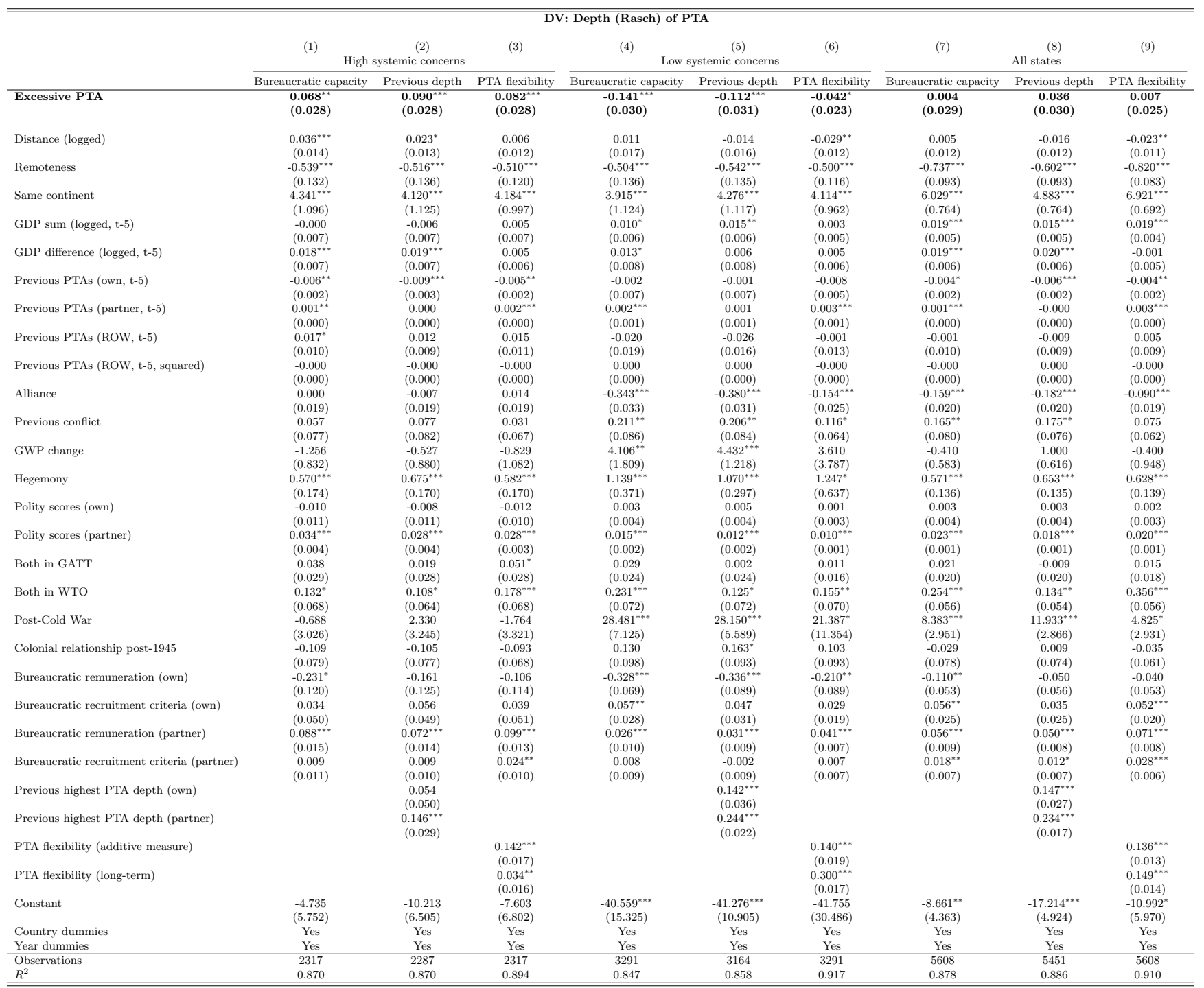

Cells contain OLS regression estimates with standard errors clustered at the undirected dyad in parentheses. DV is agreement depth (Rasch measure). ${ }^{*} p<0.10,{ }^{* *} p<0.05,{ }^{* * *} p<0.01$

The main finding is robust to these alternative model specifications. Excessive PTAs tend to be deeper, but only for those countries that demonstrate a higher level of concern for the evolution of global trade norms. The relationship between the additional control variables and PTA depth is 
largely as expected. Countries tend to sign deeper PTAs with partners who have higher levels of bureaucratic remuneration and who have previously signed deeper PTAs. The effects of a country's own bureaucratic remuneration and recruitment criteria is less clear, but this is likely due to the inclusion of country and year fixed effects. Overall, the depth of the deepest PTA previously signed by a country predicts the depth of a new PTA, although this finding does not hold for countries with a higher level of concern for the evolution of global trade norms. As expected, both measures of agreement flexibility in the DESTA data (an additive measure and a measure of the long-term flexibility of an agreement) are positively associated with PTA depth 4

\section{Testing the sequencing mechanism}

In this section I present additional robustness checks relating to the mechanism underpinning sequencing. Precedent communicates to future partners and to domestic actors the scope of agreement that is politically possible. If states sequence strategically, those states with strong systemic concerns about trade rules should successively build on past practice, 'ratcheting' the level of ambition in their PTAs. Less well-predicted PTAs should also be associated with greater increases in depth relative to previous agreements, as compared with PTAs that are better predicted.

A simple bivariate correlation between the depth of countries' PTAs and the depth of the PTA signed immediately prior indicates that the level of ambition in past agreements is a fair indication of the sort of agreement that states will sign subsequently $(r=0.52)$. For states that routinely demonstrate a strong interest in the systemic implications of WTO cases, this correlation is considerably stronger $(r=0.70)$ than for states that do not $(r=0.33)$.

We can see from the results in Table 8 that economically unlikely PTAs will be characterised by a larger increase in depth relative to previous practice. The dependent variable, DePth InCREASE, is the difference in (Rasch) depth between the current PTA and the average depth of the three preceding PTAs signed by a state. I expect this variable to be positively signed. Columns 1 and 2 present results with the sample subsetted to those states most active as third parties, while columns 3 and 4 present results subsetted to other states. The difference between the two groups is striking. For the first group, those PTAs that are less well predicted economically and politically are associated with a 0.45 increase in PTA depth when controlling for lagged exports: equivalent to an increase of half a standard deviation. For other states, PTAs that are less well-predicted economically and politically are not associated with an increase in agreement depth relative to preceding agreements.

In sum, countries that demonstrate the strongest concern for the systemic implications of global trade rules use under-predicted agreements to increase the depth of cooperation with PTA partners. Negotiating with less economically and politically salient partners affords states an opportunity to experiment in agreement design, departing from past practice by signing a more ambitious deal.

${ }^{4}$ Dür, Baccini, and Elsig 2014, Baccini, Dür, and Elsig 2015. 
Table 8: Increases in depth of agreement relative to previous agreements

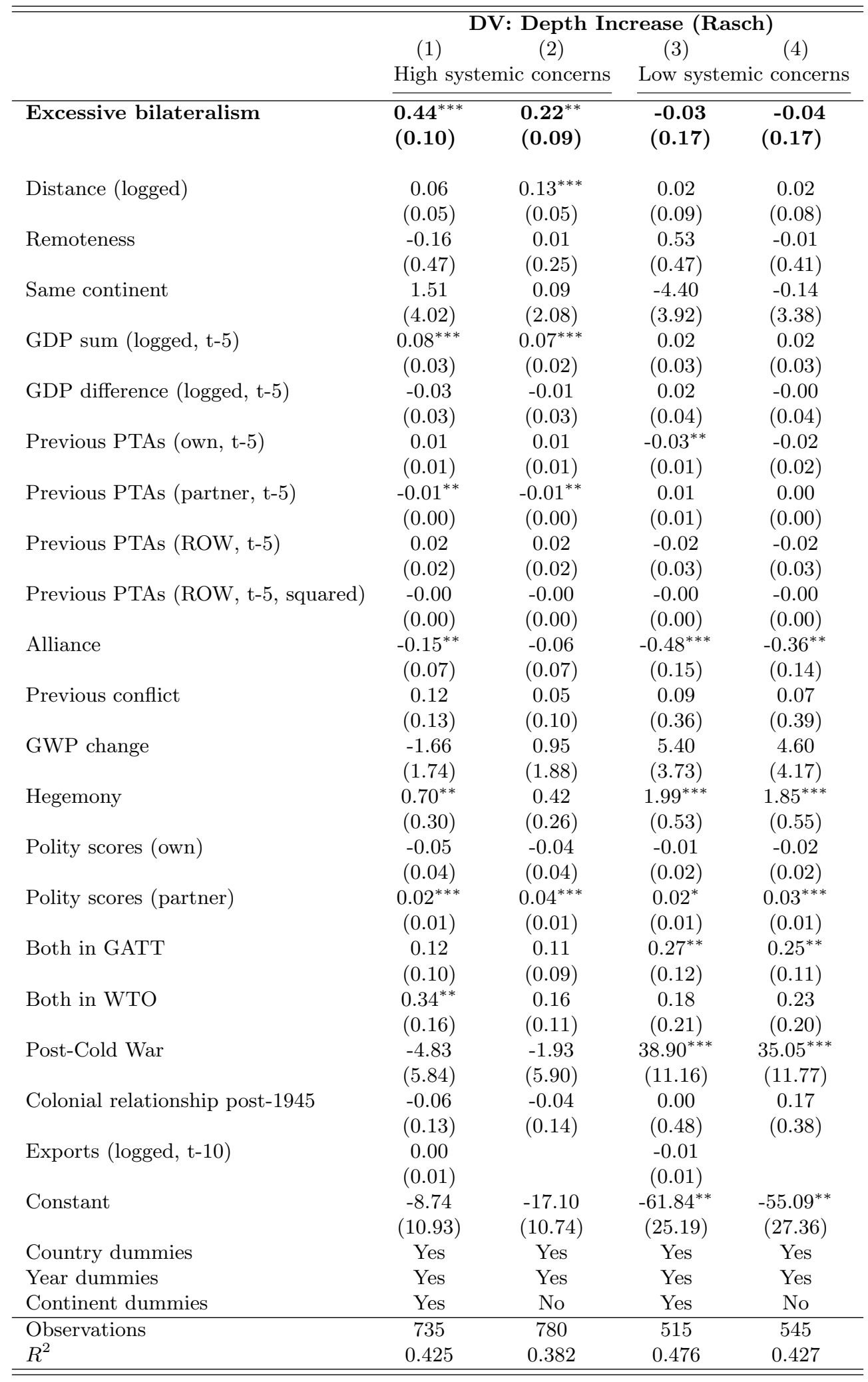

Cells contain OLS regression estimates with robust standard errors clustered at the dyad. DV is the difference in Rasch Depth of the current PTA relative to the average depth of the three preceding PTAs.

${ }^{*} p<0.10,{ }^{* *} p<0.05,{ }^{* * *} p<0.01$ 


\section{References}

Baccini, Leonardo, Andreas Dür, and Manfred Elsig. 2015. The Politics of Trade Agreement Design: Revisiting the Depth-Flexibility Nexus. International Studies Quarterly 59(12):765-775.

Baier, Scott L., and Jeffrey H. Bergstrand. 2004. Economic Determinants of Free Trade Agreements. Journal of International Economics 64 (1):29-63.

Baier, Scott L., Jeffrey H. Bergstrand, and Ronald Mariutto. 2014. Economic Determinants of Free Trade Agreements Revisited: Distinguishing Sources of Interdependence. Review of International Economics 22 (1):31-58.

Dür, Andreas, Leonardo Baccini, and Manfred Elsig. 2014. The Design of International Trade Agreements: Introducing a New Dataset. Review of International Organizations 9 (3):353-375.

Mansfield, Edward D., and Helen V. Milner. 2012. Votes, Vetoes and the Political Economy of International Trade Agreements. Princeton: Princeton University Press.

Mansfield, Edward D., Helen V. Milner, and B. Peter Rosendorff. 2002. Why Democracies Cooperate More: Electoral Control and International Trade Agreements. International Organization $56(3): 477-514$. 